\title{
Application of Hydrograph Analysis Techniques for Estimating Groundwater Contribution in the Sor and Gebba Streams of the Baro-Akobo River Basin, Southwestern Ethiopia
}

\author{
Wondmyibza Tsegaye Bayou ${ }^{1,2, *}$, Stefan Wohnlich $\left.{ }^{2}{ }^{(}\right)$, Mebruk Mohammed ${ }^{1}$ and Tenalem Ayenew ${ }^{3}$ \\ 1 Addis Ababa Institute of Technology, School of Civil and Environmental Engineering, Addis Ababa \\ University, Addis Ababa P.O. Box 385, Ethiopia; mebruk.mohammed@aait.edu.et \\ 2 Institute of Geology, Mineralogy and Geophysics, Ruhr Universität Bochum, Universitätstraße 150, \\ 44801 Bochum, Germany; stefan.wohnlich@rub.de \\ 3 College of Natural Sciences, School of Earth Sciences, Addis Ababa University, \\ Addis Ababa P.O. Box 1176, Ethiopia; tenualem@gmail.com \\ * Correspondence: wond.tsege@gmail.com
}

check for updates

Citation: Bayou, W.T.; Wohnlich, S.; Mohammed, M.; Ayenew, T. Application of Hydrograph Analysis Techniques for Estimating

Groundwater Contribution in the Sor and Gebba Streams of the Baro-Akobo River Basin, Southwestern Ethiopia. Water 2021, 13, 2006. https://doi.org/ 10.3390/w13152006

Academic Editor: Daniel Kurtzman

Received: 25 May 2021

Accepted: 14 July 2021

Published: 21 July 2021

Publisher's Note: MDPI stays neutral with regard to jurisdictional claims in published maps and institutional affiliations.

Copyright: (c) 2021 by the authors. Licensee MDPI, Basel, Switzerland. This article is an open access article distributed under the terms and conditions of the Creative Commons Attribution (CC BY) license (https:// creativecommons.org/licenses/by/ $4.0 /)$.

\begin{abstract}
The Sor and Gebba watershed has undergone several natural and anthropogenic changes, as evidenced by the physical alterations and artificial mismanagement of water resources in the watershed. These situations alter the underground storage aquifer contribution to the streams. Thus, understanding baseflow of the watershed enables us to identify the groundwater system potential and dynamicity. The main objective of this research is to estimate baseflow using several hydrograph analysis techniques as there was neither an organized groundwater resources research carried out at the watershed level nor studies on various methods on estimation of baseflow contribution to these streams. Hence, this research involves estimating baseflow from daily streamflow data using the manual hydrograph analysis technique, Flow Duration Curve (FDC), timeplot, Web-based Hydrograph Analysis Tool (WHAT), the US Geological Survey Groundwater Toolbox (USGS GW Toolbox), and the Baseflow index program (BFI+). The analysis result shows that most automated filtering techniques used with presumed parameters have estimated above-average baseflow compared to the FDC and the manual hydrograph analysis techniques. Moreover, FDC and manual hydrograph analysis resulted in a below-average value of underground storage aquifer contribution to streamflow. The BFI values are proportional for the Sor and Gebba streams and estimated about $33 \%$ for the entire watershed.
\end{abstract}

Keywords: aquifer; baseflow separation; baseflow index; FDC; streamflow hydrograph

\section{Introduction}

A hydrograph is a graphical representation of streamflow at a specific location against time. It is a watershed response as streamflow from a particular precipitation or rainfall event [1]. There are various types of hydrographs, e.g., the flood hydrograph, seasonal hydrograph, streamflow hydrograph, are few of them to mention. These hydrographs are divided into a relatively stable portion of the flow in the lower part named baseflow and a temporally fluctuating portion of the flow in the upper part called direct runoff. Baseflow released from underground storage aquifers and other delayed sources is a substantial part that sustains the streamflow of perennial streams to a prolonged dry period. Hence, determining the percentage of flow components maintaining the flow during these dry periods is useful. An interflow is usually associated with direct runoff in hilly watersheds [2-4]. Direct runoff (also called a direct surface runoff) is an immediate response from a rainfall event, channel precipitation, and part of an interflow.

Baseflow could be the principal streamflow component emerging from the underground storage aquifers during the dry season. Sometimes, baseflow comprises a higher 
portion of streamflow, even during the wet season. On some occasions, the stream could be the losing type and might not get any input from the underground storage aquifer; instead, the stream could feed an aquifer. The yield of shallow unconfined aquifers plays a vital role in the quantity of baseflow. Therefore, a shallow aquifer with a water table above a gaining stream must come from known sources to temporarily maintain streamflow [5]. Hydrograph analysis enables us to understand the origin of streamflow, aquifer storage characteristics, and its contribution to streams. Understanding the groundwater outflow processes and baseflow separation is essential to have insight into the groundwater system of the watershed.

Analyzing the baseflow part of the streamflow hydrograph started long ago as the initial theoretical studies conducted by [6-9], several other assessments recommended by [10-13], and the recent researchers [14-18], those who contributed towards the development and improvement of baseflow separation in chronological order.

Baseflow differs from groundwater recharge since groundwater pumping, direct water extraction, stream regulation, direct evaporation, transpiration, and seepage into deep aquifers might also significantly affect the proportion of baseflow $[19,20]$. Separation of baseflow from streamflow has several advantages, e.g., for the design of hydraulic structures, water supply scheme's reliability, water distribution, hydropower infrastructures, environmental water needs, and the impact of contaminants, etc. Baseflow could be affected by river regulation, artificial diversion, influent from known and unknown sources, artificial drainage, land-use changes, unplanned groundwater abstraction and withdrawal of surface water, etc.

The contribution of baseflow to streamflow could affect surface water and groundwater management practices. For example, excess pumping for water supply from an aquifer system or changing streamflow because of an over-extraction, depletion of streamflow caused by unplanned water exploitation, the water table dropping due to over-extraction, lowered baseflow due to areas vulnerability for drought, pressure on water resources, water quality deterioration, and ecological damage. Groundwater contribution to the Sor and Gebba streams is unknown, and the watershed has undergone several natural and anthropogenic changes. These changes affect recharge to groundwater and the behavior of streamflow in the watershed. Therefore, the main objective of this research is to use several hydrograph analysis techniques; viz., the manual hydrograph analysis technique, Flow Duration Curve (FDC), timeplot, the Web-based Hydrograph Analysis Tool (WHAT), the US Geological Survey Groundwater Toolbox (USGS GW Toolbox), and the Baseflow index (BFI+) for estimating the underground storage aquifers contribution to the Sor and Gebba streams.

\subsection{Description of the Watershed}

The Sor and Gebba watershed (Figure 1) is in the Southwestern part of Ethiopia located between $7^{\circ} 35^{\prime}$ and $8^{\circ} 45^{\prime}$ north latitudes and $35^{\circ} 15^{\prime}$ and $36^{\circ} 20^{\prime}$ east longitudes, and covers $6556 \mathrm{~km}^{2}$ of land, in the Oromia region and the Southern Nations, Nationalities, and Peoples Region (SNNPR). The watershed covers all or parts of the Aledidu, Chora, Darimu, Dega, Metu, Suphe, and Yayu districts (woredas) from the Illubabor Zone of the Oromia region; the Gera, Setema, and Sigmo districts from the Jima Zone of the Oromia region, and the Chena, Gesha, and Gimbo districts from the Keficho Shekicho Zone of the SNNPR.

The Sor and Gebba streams originate from the adjacent Southern Plateau ( 3000 m.a.s.l.) and flow to the valley confluence of the two streams ( 1000 m.a.s.l.). These streams make their confluence before they flow to the Birbir stream, which in turn joins, the main Baro River. The streams pass through canyon-shaped valleys and gorges. The Sor and Gebba stream hydrologic stations have been recording streamflow. These stations are ideal sites for gauging the streamflow as they are located in the confined reaches of the streams. 


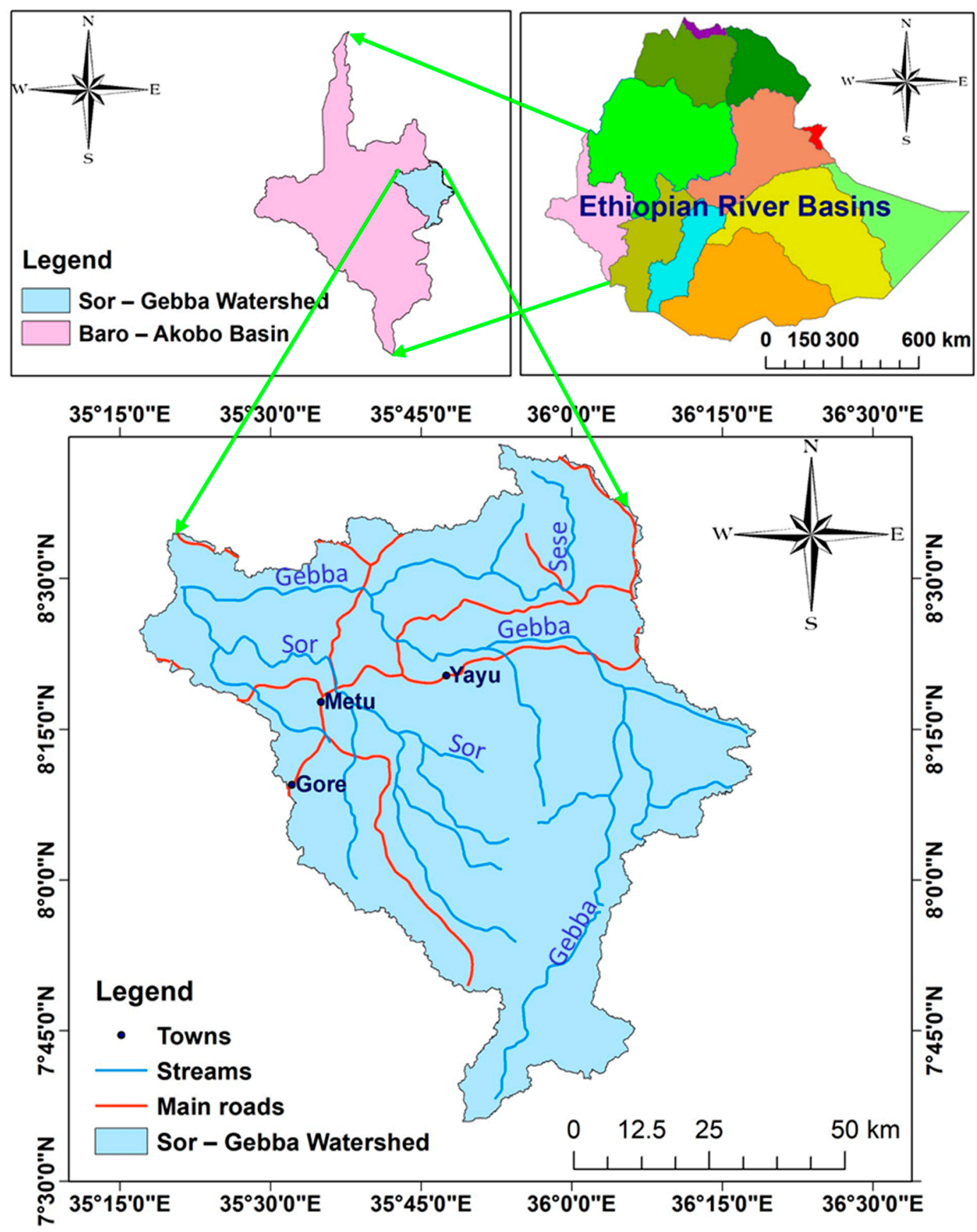

Figure 1. Location map of the Sor and Gebba watershed.

\subsection{Physiography and Climate}

The Sor and Gebba watershed has a rugged topography with mountain ranges and ridges. The undulating topography of the watershed shows the long-lasted tectonic and fluvial dissection processes. The boundary between the Illubabor plain and adjacent elevated areas is characterized by a swamp and vegetation pattern, indicating the impervious nature of the underlying ferricrete cover or cemented sedimentary deposits [21]. The central part has a gentle topography with some volcanic cliffs. Near the confluence, the streams traverse through steep valleys and deep gorges.

According to the Strahler system of stream order designation, both streams are in a watershed of fourth-order, and collectively form a stream order of five. Stream order means the streams' relative size and the degree of streams branching within the watershed. The Sor and Gebba streams exhibit sub-parallel and dendritic to sub-dendritic drainage 
patterns successively as shown in Figure 2. Sub-parallel drainage patterns exist in areas of susceptibility to erosion and regional geological structures. Due to geological controls, there could be closely spaced faults, monoclines, or isoclinal folds. The dendritic pattern prevails in rocks of uniform resistance to erosion or an inconsistent regional slope at the time of drainage inception. Drainage patterns provide important hints for the interpretation of the underlying geology [22].

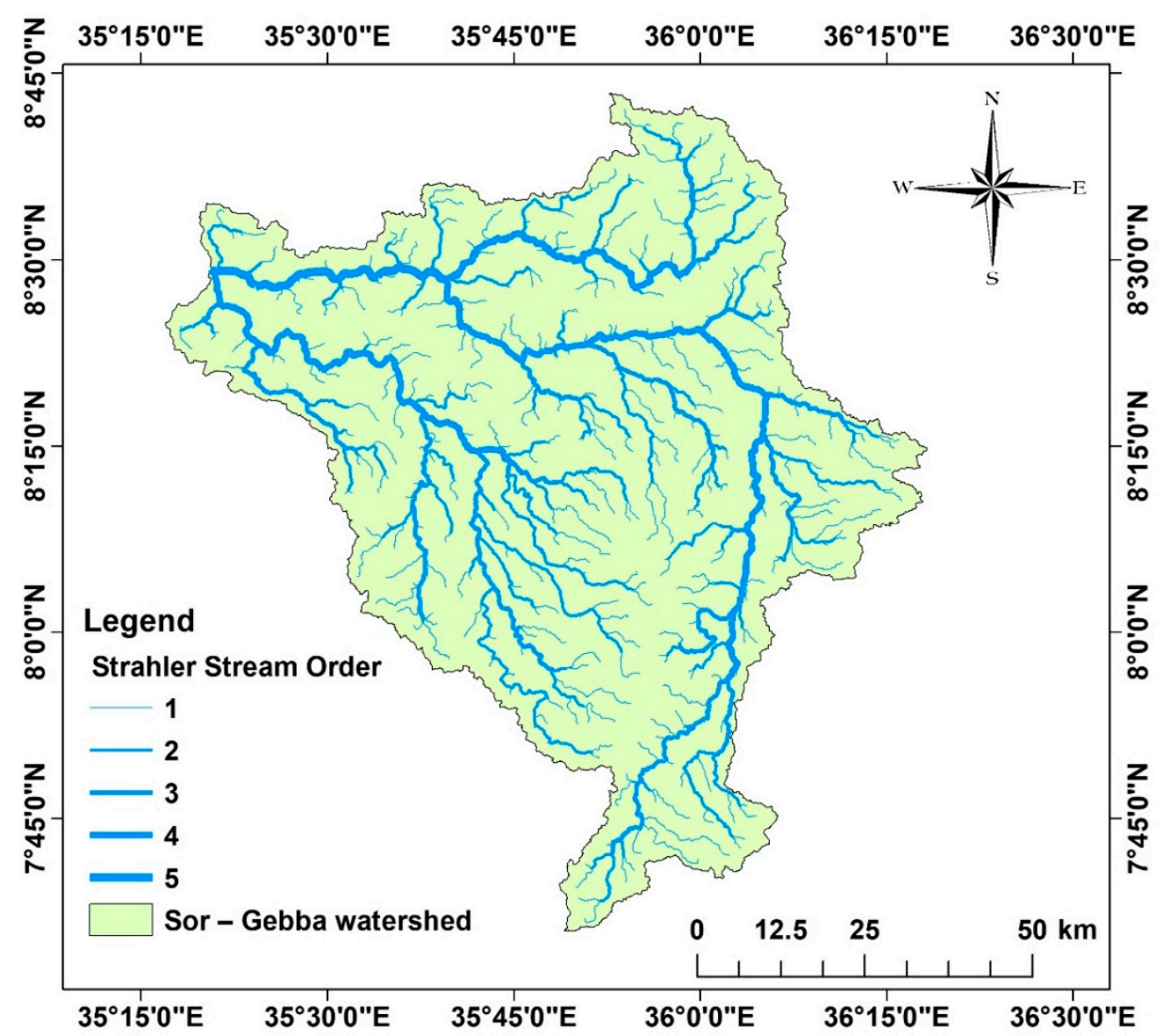

Figure 2. Strahler stream order designation for the Sor and Gebba streams.

The Sor and Gebba watershed falls in the subtropical (Woina Dega) climatic region. The average annual temperature varies between $10^{\circ} \mathrm{C}$ and $20^{\circ} \mathrm{C}$. In general, the annual average temperature decreases with an increase in altitude. Similarly to temperature and rainfall, evaporation varies with an elevation and location. High evapotranspiration values exceeding $1500 \mathrm{~mm}$ /year in the lowlands and lower values in the plateau of almost $1000 \mathrm{~mm} /$ year are common. This most humid southwestern region receives over six months of rainfall each year, where the mean annual rainfall exceeds $1800 \mathrm{~mm}$ in several places, the highest being around $2400 \mathrm{~mm}$ /year in the D. Gordomo village close to Gore town.

The Sor and Gebba vegetation is described from moderately to densely forested with broad-leaved trees and coffee plantations. This watershed is the home of the world's most famous wild coffee, Coffee Arabica. The watershed encompasses one of the five United Nations Educational, Scientific, and Cultural Organization (UNESCO) registered biodiversity sites in Ethiopia, namely, the Yayu Coffee Forest Biosphere Reserve.

Precipitation and direct runoff responses are the principal measurable components of the well-known hydrologic cycle. Baseflow is less sensitive to rainfall and is related to groundwater storage aquifers and other delayed sources of streamflow. Geology, topography, climate, soil type, vegetation, hydrologic processes, etc., affect the baseflow [23]. Some 
or most of these factors can also be affected either by anthropogenic or natural means. The natural forest vegetation is supposed to support sustainable rainfall that recharges and feeds the groundwater. However, some parts of the forest in the watershed get cleared due to land-use changes. Understanding the baseflow contribution to streamflow is necessary for various water resources planning, development, and management practices. Hydrograph analysis and interpretation is a well-known system for understanding the groundwater system dynamics and potential.

\subsection{Geology and Hydrogeology}

The general geological succession of the upper Baro River Basin is Precambrian crystalline basement rocks overlain by the late Paleozoic to early Tertiary sediments, and these sediments overlain by the Cenozoic volcanic rocks and accompanying sedimentary rocks. Though the general extent of each is unknown, all the three major rock types, the Precambrian basement rocks, the Tertiary-Quaternary volcanic rocks, and the thick continental Neogene sediments, exist in varying depths and lateral coverage [21,24-26]. The same is true in the Sor and Gebba watershed.

Metamorphic rocks comprise the Archean granitic gneiss and loose sediments lithified by heat and pressure. Most of these rocks are relatively impermeable and considered aquitard in the groundwater system. Since their formation, these rocks have been subjected to several orogenic incidents, combined with the rifting linked with the development of the red sea and the Main Ethiopian Rift (MER) that resulted in considerable fracturing and shattering [27]. Middle Proterozoic to Archean medium-coarse-grained high-grade gneiss and migmatites, and Pre and Syn-tectonic granitoid rocks are the predominant rock types in the watershed. The first one being the Precambrian crystalline basement rock that has existed for over 540 million years (Ma) [26,28], covering 20\% of the watershed, and the second one being Cenozoic volcanic rocks that exist in the ranges from 50 to $10 \mathrm{Ma}$ and compose $80 \%$ of the watershed as shown on the map produced by the Geological Survey of Ethiopia (GSE) [29]. We can find these Precambrian basement rock exposures in areas where the region is not affected by Cenozoic volcanism and rifting. It associates the regional aquifer in the mountain ranges and the principal water sources with the fracture zones where these predominant rocks are strongly foliated.

The formation of sedimentary rocks ended up with Paleozoic erosion and deposition. Sedimentation in this region has ended with clay, silt, sand, and conglomerates deposition $[30,31]$ that may change to siltstone, mudstone, claystone, coal, and shale overlying the basement rocks. This formation made up of these fine-grained sediments is considered an aquitard. The rock formation has been formed on the earth's surface through biochemical actions. Volcanic rocks are derived from the cooling of molten magma and could be either intrusive or extrusive. In the Sor and Gebba watershed, these fractured and weathered Tertiary volcanic rocks make up the principal aquifer [30]. However, the Quaternary volcanic rocks are aquitards except where scoriaceous nature has determined it a good aquifer [26].

The geological formation of the Sor and Gebba watershed and the surrounding area could be associated with regional geology. It includes gneissic granite rocks of the Mozambique tectonic belt such as the Precambrian crystalline basement rocks, Tertiary lower tracheae, Tertiary basaltic flow, phonolites, and tracheae dikes and Quaternary alluvial loose sediments from the oldest to the youngest [32]. The GSE 1:250,000 scale geological map of the Sor and Gebba watershed depicts that the watershed is covered by the Makonnen Basalts (PNmb): flood basalts, commonly directly overlying the crystalline basement; the Alge Group (ARI): biotite and hornblende gneisses, granulite and migmatite with minor metasedimentary gneisses; the Nazareth Series (Nn): ignimbrites, unwelded tuffs, ash flows, rhyolitic flows, domes, and trachyte units, Jimma Volcanics (Pjb) and pre-tectonic and syn-tectonic granitoid (Gt1) (Figure 3). The predominant rock covering the Gore area is volcanic rock seen by some plugs existing around the town. 


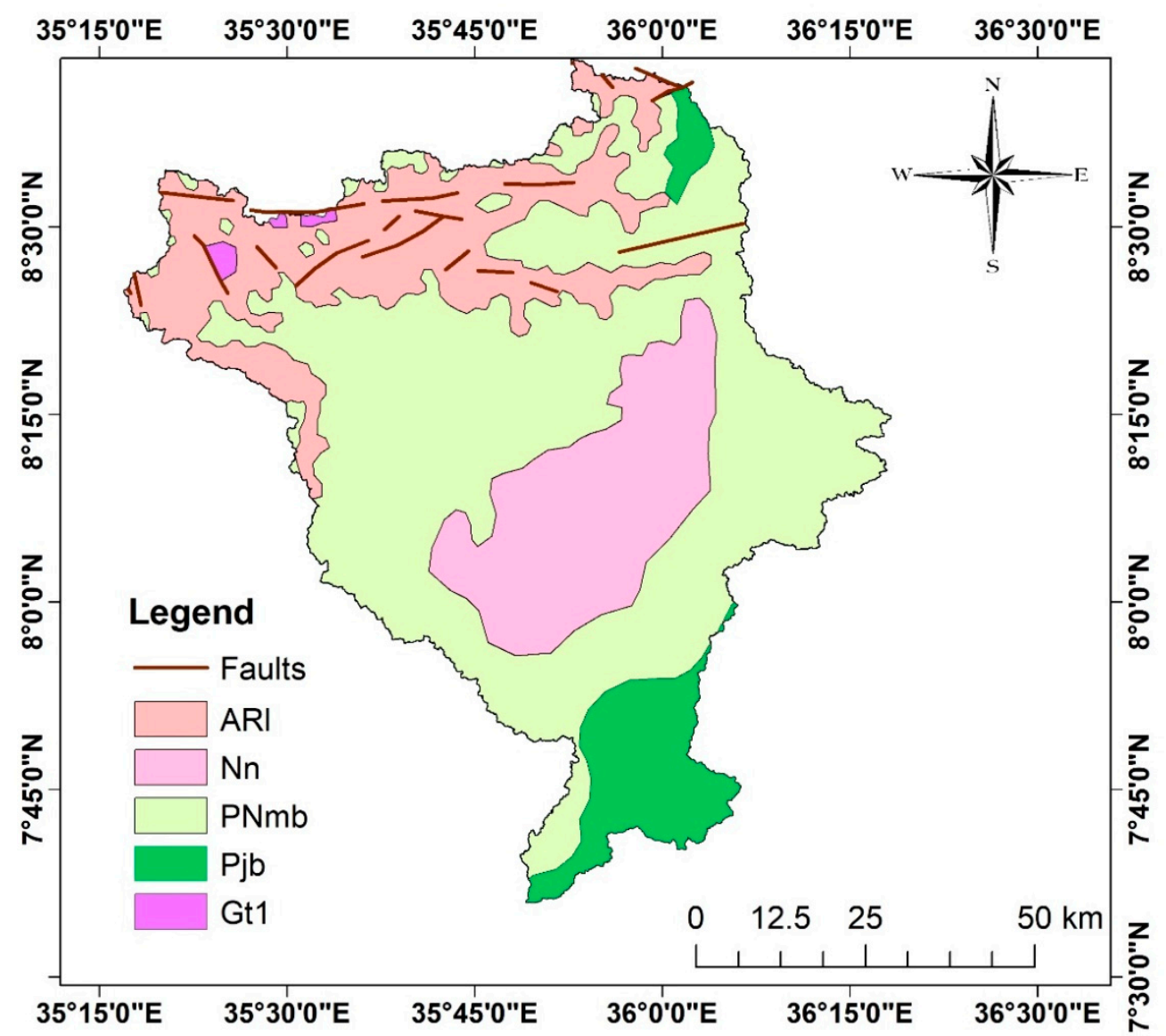

Figure 3. Geological map of the watershed (modified from GSE, 2005; 1:250,000).

The southwestern part of Ethiopia is affected by the tectonic phenomenon. As a result, a series of faults, folds, fractures, and lineaments have been recognized. These geological structures have a dominant trend direction of E-W, NE-SW, and WNW-ESE as shown in Figure 4. Secondary geologic structures, such as faults, fissures, and fractures, give rise to recharge the deep groundwater [21,24,33-36]. The streams dominantly flow in the general E-W direction following the alignment of geological structures.

From the hydrogeological perspective, the topmost part of the weathered, jointed, and fractured gneissic and Tertiary volcanic rocks is considered as the source of recharge for groundwater (Figure 4). However, Precambrian basement rocks and Quaternary volcanic rocks in the plateau are intact and massive. There might be geologic structures created due to fracturing and tectonic disintegration that allow water transmission through it. There is a development of marsh where the rocks get impermeable near the surface.

Local recharge dominates in humid climates and adjacent areas of high rainfall regions. The occurrence of several springs is an indication of the presence of an aquiclude between the volcanic rocks and the basement and confirms a direct link between shallow groundwater and rainfall in the watershed. This is a better opportunity for groundwater exploitation and spring development in the watershed. Springs and wetlands are also good sources of recharge and baseflow. In general, the Sor and Gebba watershed is predominantly a recharging zone.

Soil types resulted from and going with the geology guide the undulating topography and the geomorphic characteristics of the watershed. According to the Food and Agricultural Organization of the United Nations (FAO) [37], the predominant soils covering the watershed are cambisols, lithosols, and acrisols (Figure 4). Derivatives of the felsic and metamorphic Precambrian basement rocks and Tertiary trap volcanic rocks formed the 
dominant laterite soil that caused the watershed to have less infiltration capacity. However, the laterite soil is the dominant source of shallow groundwater [34].

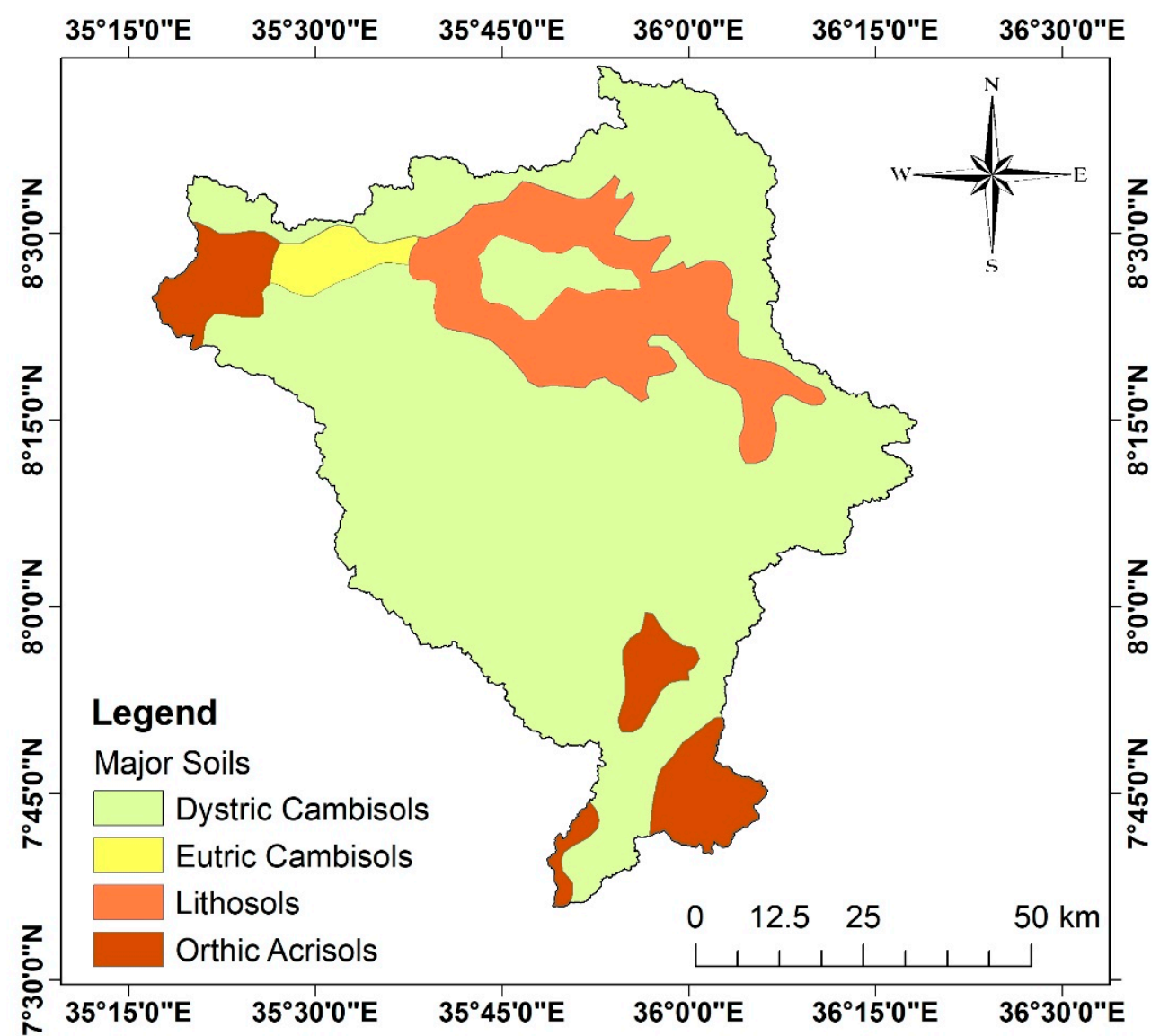

Figure 4. Major soils map of the watershed (modified from UNDP and FAO, 1984).

Cambisols contain some weathered materials in the sediment. Generally, cambisols happen in regions with surplus precipitation, but where terrain positions permit excess runoff. Based on the FAO [38], they are medium textured, have high porosity, moderate water retention capacity, and internal drainage. Acrisols belong to strongly weathered acidic soils and clay. Under protective forest cover, acrisols have a porous surface. Clearing the forest destroys and removes the valuable top horizon to the form a hard surface crust that allows harmful surface erosion. On the other hand, lithosols consist of poorly weathered rock stratified without a definite profile. In the lithosols region, one can find thick alluvial deposits and an outcrop of aphanitic basalt flow.

\section{Materials and Methods}

\subsection{Data Sources, Collection, and Analysis}

Streamflow is an indication of the hydrological response of a watershed upstream of the streamflow-gauging station under consideration. Streamflow data were freely available upon request from the Ethiopian Ministry of Water, Irrigation, and Energy (MOWIE). Daily streamflow data were collected and evaluated at the two hydrological gauging stations: Gebba near Suphe $\left(8^{\circ} 29^{\prime}\right.$ N Lat., $35^{\circ} 39^{\prime}$ E Lon.) and Sor near Metu $\left(8^{\circ} 19^{\prime}\right.$ N Lat., $35^{\circ} 36^{\prime}$ E Lon.). At the confluence $\left(8^{\circ} 29^{\prime} \mathrm{N}\right.$ Lat., $35^{\circ} 21^{\prime} \mathrm{E}$ Lon.), the total area of the watershed under study being $6556 \mathrm{~km}^{2}$, the drainage area at the Gebba gauging site estimated to be 3894 $\mathrm{km}^{2}$ and data are available for the period 1976-2018 and the corresponding value for the Sor is $1622 \mathrm{~km}^{2}$ and data are available from 1974 to 2018. A total of 30 years (1986-2015) of records from these stations were used based on the WMO [39] procedure for data analysis. 
There were missing data in both stations. The cause for the data gap might be due to a lack of focus, knowledge gap, an internal unrest, and many other factors in the region that interrupted the flow records for some time. The first step was infilling the missing data. Continuous daily flow data for each year were plotted on a spreadsheet and checked to correct a significant change in magnitude and frequency. For the infilling of the missing data, regression analysis, linear interpolation, or one of these techniques were used. Daily time-series flow data for the Sor and Gebba streams were then plotted (Figure 5).

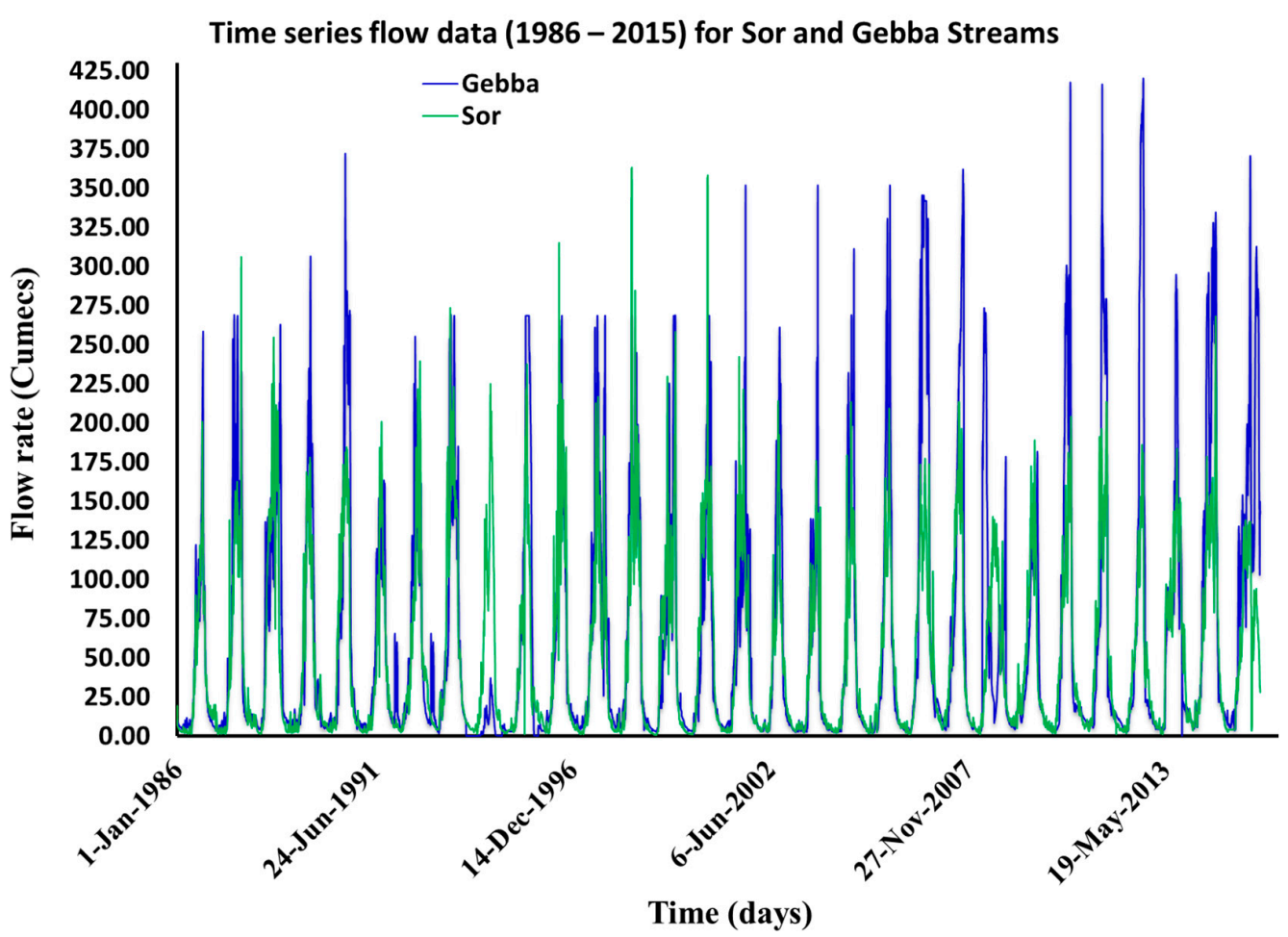

Figure 5. Time series streamflow of Sor near Metu and Gebba near Suphe from 1986 to 2015.

Daily precipitation (PPT) and temperature data from 18 meteorological stations found within and around the watershed were gathered from the National Meteorology Agency (NMA) (Figure 6 and Table 1). However, no latest data are available for some stations and no data for some other locations. The long-term average data of the FAO local climate estimator (New_LocClim_1.10 software) database include data from 1961 to 1990 and beyond, and this is compared with concurrent meteorological data having one climatic period. The variation between the long-term average of the FAO New_LocClim_1.10 precipitation data and precipitation values from the meteorological stations was insignificant. Therefore, the basis for the analysis considered the long-term average FAO New _LocClim_1.10 database. Potential evapotranspiration (PET) was directly estimated from the FAO New_LocClim_1.10 database. Weather was assumed not to change that much in the climatic period. In addition to the daily hydrological data (surface water discharge data) collected from MOWIE, this study used geological maps from the GSE, soil maps from the UNDP and FAO, and a master plan study on water resources from MOWIE. 


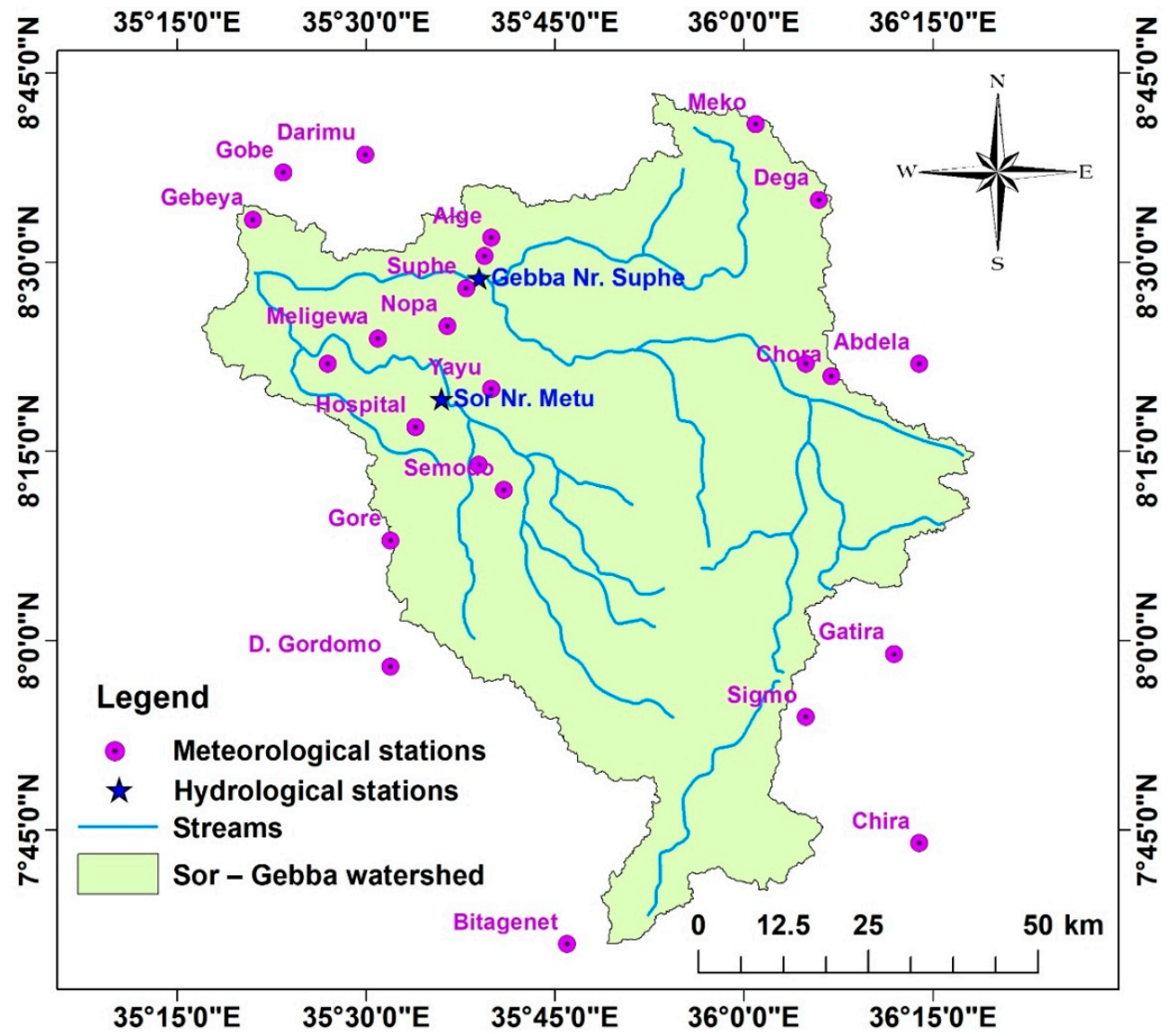

Figure 6. Location and distribution of meteorological and hydrological stations.

Table 1. Meteorological and hydrological stations considered for this study.

\begin{tabular}{|c|c|c|c|c|c|}
\hline S. No & Zone & Meteorological Station Name & Years of Data & $\begin{array}{l}\text { Coordinates } \\
\text { (Lat, Lon) }\end{array}$ & $\begin{array}{c}\text { Average Rainfall } \\
\text { (mm/year) }\end{array}$ \\
\hline 1 & Ilubabor & Abdela & 1982-1998 & $8^{\circ} 22^{\prime}, 36^{\circ} 15^{\prime}$ & 1941.01 \\
\hline 2 & Ilubabor & Alge & 1980-1996 & $8^{\circ} 32^{\prime}, 35^{\circ} 40^{\prime}$ & 1843.70 \\
\hline 3 & Ilubabor & Bilambilo & $2008-2011$ & $8^{\circ} 14^{\prime}, 35^{\circ} 39^{\prime}$ & 1825.43 \\
\hline 4 & Ilubabor & Chora & 2008-2009 & $8^{\circ} 22^{\prime}, 36^{\circ} 07^{\prime}$ & 1795.33 \\
\hline 5 & Ilubabor & D. Gordomo & 1980-2009 & $7^{\circ} 58^{\prime}, 35^{\circ} 32^{\prime}$ & 2378.39 \\
\hline 6 & Ilubabor & Darimu/Dipa & 1984-1995 & $8^{\circ} 36^{\prime}, 36^{\circ} 11^{\prime}$ & 1915.89 \\
\hline 7 & Ilubabor & Dega & $2007-2010$ & $8^{\circ} 35^{\prime}, 36^{\circ} 07^{\prime}$ & 1027.32 \\
\hline 8 & Ilubabor & Fugo leka / Metu & 1967-1997 & $8^{\circ} 18^{\prime}, 35^{\circ} 35^{\prime}$ & 1833.82 \\
\hline 9 & Ilubabor & Gore & $1953-2010$ & $8^{\circ} 09^{\prime}, 35^{\circ} 32^{\prime}$ & 1801.31 \\
\hline 10 & Ilubabor & Hurumu/Yayu & $1972-2010$ & $8^{\circ} 20^{\prime}, 35^{\circ} 40^{\prime}$ & 1923.27 \\
\hline 11 & Ilubabor & Meligewa & $1987-1995$ & $8^{\circ} 24^{\prime}, 35^{\circ} 31^{\prime}$ & 1748.90 \\
\hline 12 & Ilubabor & Nopha & 1978-1995 & $8^{\circ} 25^{\prime}, 35^{\circ} 36^{\prime}$ & 1867.42 \\
\hline 13 & Ilubabor & Semodo & $1987-1996$ & $8^{\circ} 12^{\prime}, 35^{\circ} 41^{\prime}$ & 1803.56 \\
\hline 14 & Ilubabor & Sortefasses & 2009 & $8^{\circ} 22^{\prime}, 35^{\circ} 27^{\prime}$ & 1846.73 \\
\hline 15 & Ilubabor & Suphe & 1980-1995 & $8^{\circ} 30^{\prime}, 35^{\circ} 39^{\prime}$ & 1587.30 \\
\hline 16 & Ilubabor & Wutete & 2005-2009 & $8^{\circ} 22^{\prime}, 36^{\circ} 05^{\prime}$ & 1741.45 \\
\hline 17 & Jima & Chira & 1979-1996 & $7^{\circ} 44^{\prime}, 36^{\circ} 14^{\prime}$ & 1988.91 \\
\hline \multirow[t]{3}{*}{18} & Jima & Gatira & 1984-1997 & $7^{\circ} 59^{\prime}, 36^{\circ} 12^{\prime}$ & 1905.45 \\
\hline & & Average & & & 1820.84 \\
\hline & & Hydrological Stations & & & Flow $\left(\mathrm{m}^{3} / \mathrm{s}\right)$ \\
\hline 1 & Ilubabor & Sor near Metu $\left(1622 \mathrm{~km}^{2}\right)$ & 1974-2018 & $8^{\circ} 19^{\prime}, 35^{\circ} 36^{\prime}$ & 51 \\
\hline 2 & Ilubabor & Gebba near Suphe $\left(3894 \mathrm{~km}^{2}\right)$ & $1986-2018$ & $8^{\circ} 29^{\prime}, 35^{\circ} 39^{\prime}$ & 59 \\
\hline 3 & Ilubabor & Sor-Gebba Junction $\left(6556 \mathrm{~km}^{2}\right)$ & Transposition & $8^{\circ} 29^{\prime}, 35^{\circ} 21^{\prime}$ & 138 \\
\hline
\end{tabular}


The Digital Elevation Model (DEM) (Figure 7) is a digital representation of the Earth's surface elevation to a reference datum. DEM is used to determine terrain attributes such as elevation, land surface slope, the slope direction, the aspect, drainage divide in the watershed, etc. Additional geospatial data for the Sor and Gebba watershed were downloaded from the Advanced Land Observing Satellite (ALOS Global Digital Surface Model "ALOS World 3D-30m" (AW3D30), accessed 12 September 2019 from website (https: / / www.eorc.jaxa.jp/ALOS/en/aw3d30/index.htm)), and then processed with ArcGIS 10.5 software. Hydrological and meteorological station's locations, drainage pattern and stream order, geological controls viz., faults, creating the 3D information of geological features, soil data, and watershed outline were processed using the ArcGIS 10.5 software.

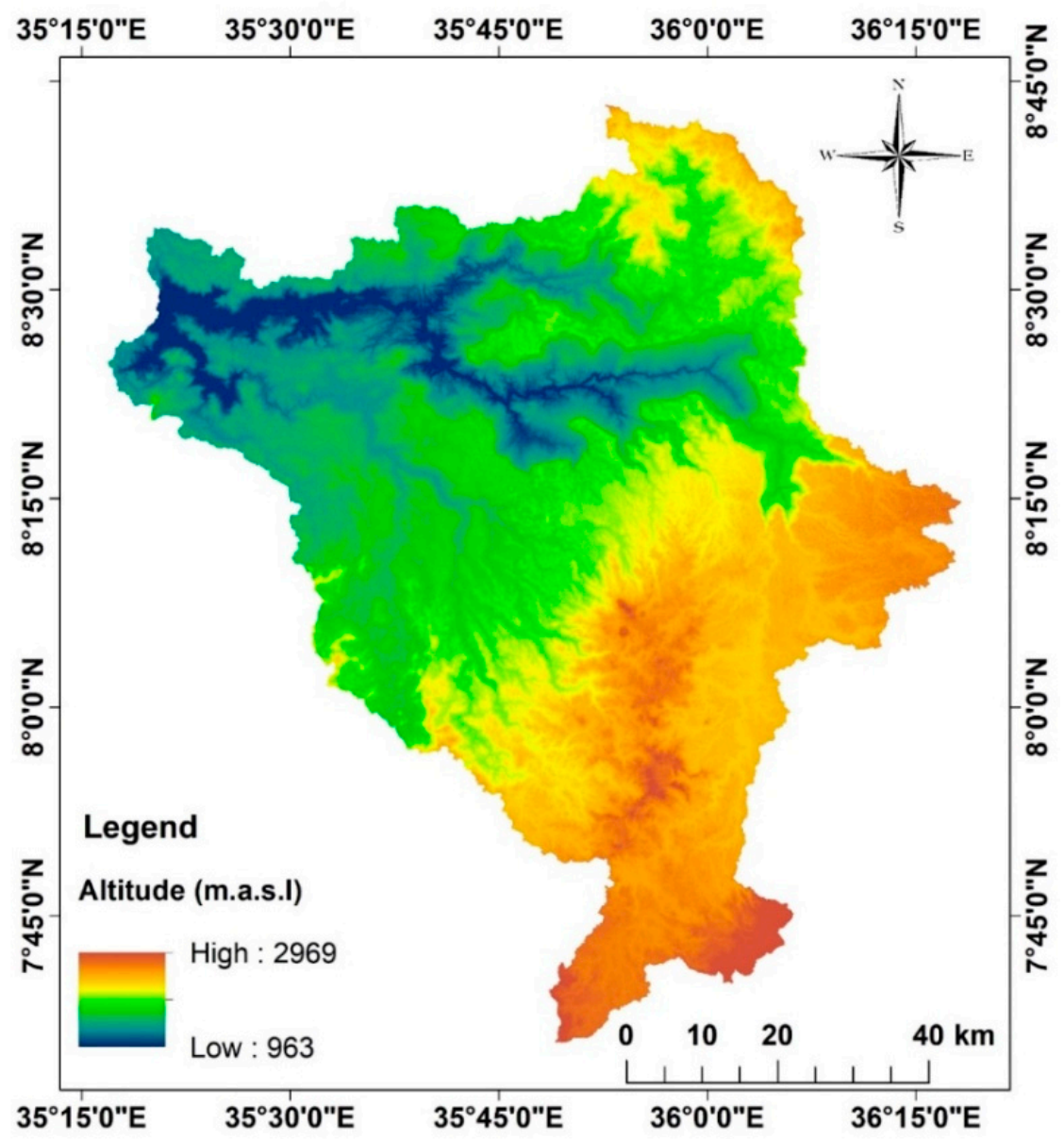

Figure 7. Digital Elevation Model of the watershed (ALOS World 3D-30m database).

\subsection{Hydrograph and Models Used}

The Flow Duration Curve (FDC) is a graphical and analytical frequency curve showing the percentage of time given streamflow was equaled or exceeded a specific value during a defined period. The curve displays a lot of hydrologic information about streamflow, including the influence of climate, physiography, and geology combined in a single graphical map. It conveys a multitude of complex hydrologic information to decision-makers. The application of FDC in resolving water resource problems includes the management of surface water quality, irrigation and hydropower water usage planning, flood control, and streamflow characterization $[40,41]$.

FDC can be constructed by following either the calendar year method, the total period method, or the class interval method. This study used the total period method. FDC was 
plotted from daily streamflow data using the unbiased estimates of the Weibull's plotting position given by:

$$
P=100 \frac{m}{(n+1)}
$$

where $P$ is the probability that a given flow will be equaled or exceeded (\%); $m$ is the rank when flows arrange in descending order; $n$ is the total number of records.

The shape of the curve in the high flow region indicates the type of flood that the stream is exhibiting; further, the curve shape in the low flow region indicates the watershed's capacity to sustain flow during the dry period. Generally, Q50 represents the median flow that is not affected by very high or low flows. A flow exceedance greater than or equals to Q50 is understood to be a low flow [42,43]. The ratio Q90/Q50 denotes a percentage of underground storage aquifer contribution to the streamflow $[15,44,45]$.

Streamflow from a watershed is composed of direct surface runoff resulting from precipitation and baseflow derived from groundwater or other delayed sources $[9,13,15,44]$. Several techniques such as the graphical method, analytical methods, digital filter techniques, and recession curve method have been used for baseflow separation [42,43,46]. Most automated computer programs used to separate the streamflow into baseflow and direct runoff were as follows:

$$
Q_{t}=B F_{t}+D R_{t}
$$

where $Q_{t}$ is the streamflow; $B F_{t}$ is the baseflow; $D R_{t}$ is the direct runoff (all in Cumecs or $\mathrm{m}^{3} / \mathrm{s}$ ) at any time $t$.

Graphical baseflow separation techniques such as the constant discharge method, the constant slope method, the convex method, and the concave method shown in Figure 8 are suitable for baseflow separation. These graphical baseflow separation methods are more tedious than the automated methods and do not provide consistent results $[13,44,47,48]$. Linsley et al. [10] gave the most common method to get the point where the direct runoff ends upon the falling limb of the hydrograph, as follows:

$$
N=0.83 A^{0.2}
$$

where $N$ is the number of days between the peak and the end of direct runoff; $A$ is watershed area in $\mathrm{km}^{2}$.

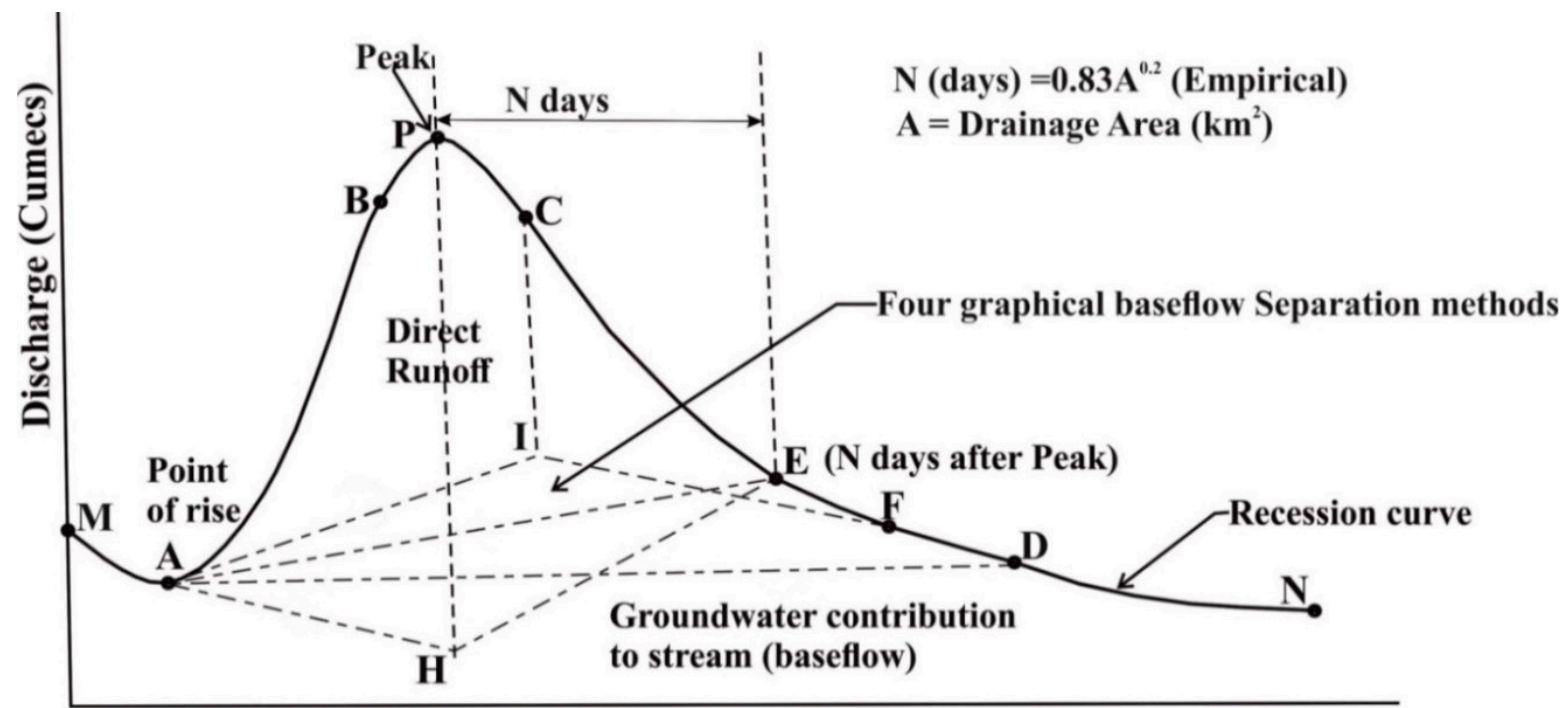

Time (hrs or days)

Figure 8. Graphical baseflow separation techniques modified from [49]. 
The concave method applied in this research extends from the onset of the falling limb until it meets the line drawn vertically down from the inflection point and then joins the minimum in the rising limb back with the " $\Lambda$ " shape. The recession curve can be represented by an exponential equation as follows:

$$
Q_{t}=Q_{o} e^{-\alpha t}
$$

where $Q_{t}$ is flow rate at time $t ; Q_{o}$ is initial flow rate at the start of recession segment; $\alpha$ is constant; high recession constant, $k=e^{-\alpha}>0.9$, means dominance of baseflow.

Several investigations related to the evaluation of baseflow in watersheds include using one of the automated methods as mentioned by [46], such as the baseflow index (BFI) (standard and modified), Hydrograph Separation Program (HYSEP), Streamflow partitioning method (PART), WHAT, Bflow, BFI+, etc. HYSEP is a computer program that takes as a model three manual hydrograph analysis techniques: the fixed interval, the sliding interval, and the local minimum [50]. The local minimum, PART [51], and UKIH (the United Kingdom, Institute of Hydrology now UK Centre for Ecology \& Hydrology) smoothed minimum [52] methods consist of connecting local minimum points of the hydrograph with straight lines. They differ in how the local minimum is identified.

The Bflow program [53] uses a baseflow separation method first suggested by [54]. In the frequency range of a hydrograph, the low frequency will be more likely related to the baseflow; in contrast, the high-frequency variability of the streamflow will mainly be from direct surface runoff. Therefore, it should be possible to distinguish the baseflow by lowpass filtering. The BFI introduced by UKIH can be estimated from measured streamflow data. BFI can be utilized for estimation of the baseflow characteristics of watersheds. The theoretical limit of BFI is between 0 and 1. Generally, this index can vary from 0.15 to 0.20 for an impermeable watershed and can be more than 0.95 for some permeable watersheds. The BFI relates to the watershed characteristics such as soil type, geology, topography, vegetation, hydrological parameters, and climate [43,44,46,55].

The Recursive Digital Filter (RDF) is the most commonly used method for separating streamflow into a baseflow and direct runoff. There are two well-known RDFs: the Eckhardt [56] and the commonly used Chapman algorithms [57]. These filtering techniques have no basis in separating streamflow into baseflow and direct runoff but provide an easily automated flow index that can be easily related to the baseflow. This index is the long-term ratio of baseflow to the streamflow. Digital filters calculate baseflow and calibrate parameter values using daily streamflow data. All digital filters calculate baseflow by using the records of streamflow at day one (i), earlier day one (i-1) parameter values, and constants calculated using daily streamflow data and user-determined $B F I_{\max }$. The automated recursive filtering algorithm by [3] calculates the direct runoff as follows:

$$
D R_{t}=\alpha D R_{t-1}+\beta(1+\alpha)\left(Q_{t}-Q_{t-1}\right)
$$

where $D R$ is direct runoff in Cumecs; $Q$ is streamflow in Cumecs; $\alpha$ is filter parameter equal to 0.925 as a first estimate; $\beta$ is coefficient equal to 0.5 , and $t$ is the time step.

Chapman [57] discussed the second RDF algorithm as follows:

$$
D R_{t}=\frac{3 \alpha-1}{3-\alpha} D R_{t-1}+\frac{2}{3-\alpha}\left(Q_{t}-Q_{t-1}\right)
$$

where $D R$ is the direct runoff in Cumecs; $Q$ is the streamflow in Cumecs; $\alpha$ is the filter parameter values ranging from 0.925 to 0.995 , and $t$ is the time step.

Average daily flow rates at the two hydrological gauging stations (Sor near Metu and Gebba near Suphe) and another transposed station at the confluence of these two streams, were evaluated by the method suggested by [58]. The Eckhardt [56] approach, developed to achieve low-pass digital filtering of the streamflow hydrograph for baseflow partition, can be mathematically expressed by: 


$$
B F_{t}=\frac{\left(1-B F I_{\max }\right) \alpha B F_{t-1}+(1-\alpha) B F I_{\max } Q_{t}}{1-\alpha B F I_{\max }}
$$

where $B F$ is baseflow (Cumecs); $B F I_{\max }$ is the maximum value of baseflow index; $Q$ is streamflow (Cumecs), and $\alpha$ or filter parameter is subject to the $B F \leq Q$ at any time $t$.

Two parameters are required for the Eckhardt filtering technique [56]: (i) the recession constant, $\alpha$ (Eckhardt parameter), which is defined based on the recession curve of the streamflow hydrograph estimate; (ii) $B F I_{\max }$, that cannot be measured, but can be improved on the basis of other method results. Eckhardt [56] introduced three typical BFI $I_{\max }$ values for various hydrogeological and hydrological settings:

$B F I_{\max }=0.80$ for perennial streams with porous aquifers;

$B F I_{\text {max }}=0.50$ for ephemeral streams subjected to permeable aquifers;

$B F I_{\max }=0.25$ for perennial streams with hard rock aquifers.

In this study, a $B F I_{\max }$ of 0.25 was used as an initial estimate since the watershed geology was likely to be hard rock aquifer and the streams perennial [43,56,59].

Using the FDC technique, the long-term mean annual fraction of the streamflow from the baseflow was estimated after obtaining the Q90 and Q50 values and connecting Equation (7) with FDC $[43,44]$. Then, by considering $\alpha=0.925$ as an initial value $[15,53]$, and performing the filtering daily flow for various parameter values of $\alpha$ up to when the BFI was equivalent to the Q90/Q50 ratio, applying the filtered $\alpha$ enables obtaining several baseflow time-series records. The long-term average BFI values indicate hydrogeological conditions. A higher BFI value means the release of more water from the underground storage aquifers.

Web-based Hydrograph Analysis Tool (WHAT) accessed 15 November 2019 from website (http:/ / engineering.purdue.edu/ what) developed by [60], a mapping and graphical interface computer program (USGS GW-Toolbox) accessed 15 November 2019 from website (http:/ /water.usgs.gov/software/lists/groundwater/) sourced from [61], and HydroOffice tool (BFI+) accessed 25 October 2019 from website (http:/ /hydrooffice.org/) created by [62] give an impression of being practical tools which can separate the baseflow through hydrograph analysis. The WHAT program comprises three methods, the local minimum, one parameter, and two-parameter filters.

The USGS GW Toolbox contains eight techniques inclusive of two recursive digital filtering methods. It analyses the same data using all these techniques. These eight hydrograph analysis methods allow estimating the baseflow and surface runoff. The toolbox incorporates the BFI (the standard and the modified one), HYSEP (fixed interval, local minimum, and sliding interval), RDF (one parameter, and two parameters), and PART hydrograph separation methods and the RORA program for recession curve displacement and supporting RECESS for estimating recharge to groundwater.

HydroOffice tool encompasses eleven methods, out of which three are the fixed interval, the local minimum, and the sliding interval. The other eight are RDF (oneparameter algorithm, Boughton two-parameter, IHACRES three-parameter, Bflow (Lyne \& Holick algorithm), Champman algorithm, Furey \& Gupta filter, Eckhardt filter, EWMA filter). These eight RDF algorithms are summarized and shown in Table 2 below. 
Table 2. Summary of RDF used in BFI+ Program modified from [62].

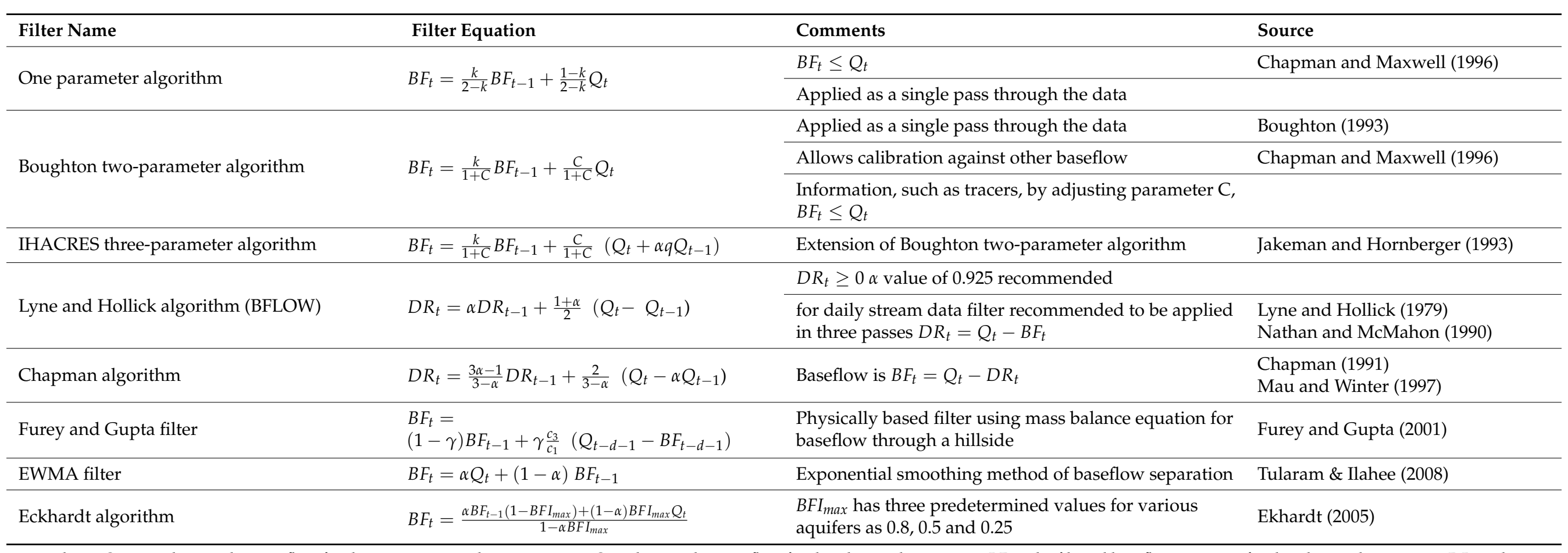

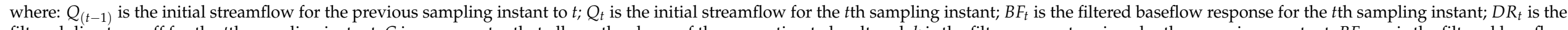

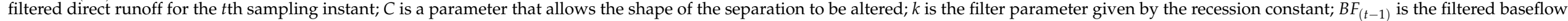
response for the previous sampling instant to $t ; \gamma, c_{1}, c_{3}$; are physically based parameters. $D R_{(t-1)}$ is the filtered direct runoff for the previous sampling instant to $t ; \alpha, \alpha q$ are filter parameter. 


\section{Results and Discussion}

The Sor and Gebba watershed is a typical mountainous plateau that receives adequate rainfall throughout the year. An analysis of data from 18 meteorological stations distributed within and around the watershed between 1953 and 2011 showed unimodal rainfall with almost $300 \mathrm{~mm} /$ month in wet and $30 \mathrm{~mm} /$ month in dry periods. The total mean annual precipitation (1961-1990) (NMA data and FAO New_LocClim_1.10 databases provided somewhat the same results) and the evapotranspiration based on the same FAO Penman-Monteith database from the watershed were $1822 \mathrm{~mm}$ and $1262 \mathrm{~mm}$, respectively (Table 3 and Figure 9). Since the watershed receives adequate rainfall and sufficient moisture availability throughout the year, one can assume that the actual and potential evapotranspiration are comparable. Hence, the difference between precipitation and potential evapotranspiration results totaled a net precipitation of $560 \mathrm{~mm}$.

Table 3. Comparison of long-term (1961-1990) PPT and PET (NMA and FAO LocClim database).

\begin{tabular}{ccccccccccccc}
\hline Months & Jan & Feb & Mar & Apr & May & Jun & Jul & Aug & Sep & Oct & Nov & Dec \\
\hline PPT $(\mathrm{mm})$ & 22 & 32 & 73 & 96 & 217 & 290 & 291 & 304 & 273 & 146 & 59 & 22 \\
PET $(\mathrm{mm})$ & 113.48 & 111.33 & 131.33 & 124.83 & 109.23 & 92.73 & 86.55 & 84.25 & 94.45 & 108.12 & 101.55 & 104.48 \\
\hline
\end{tabular}

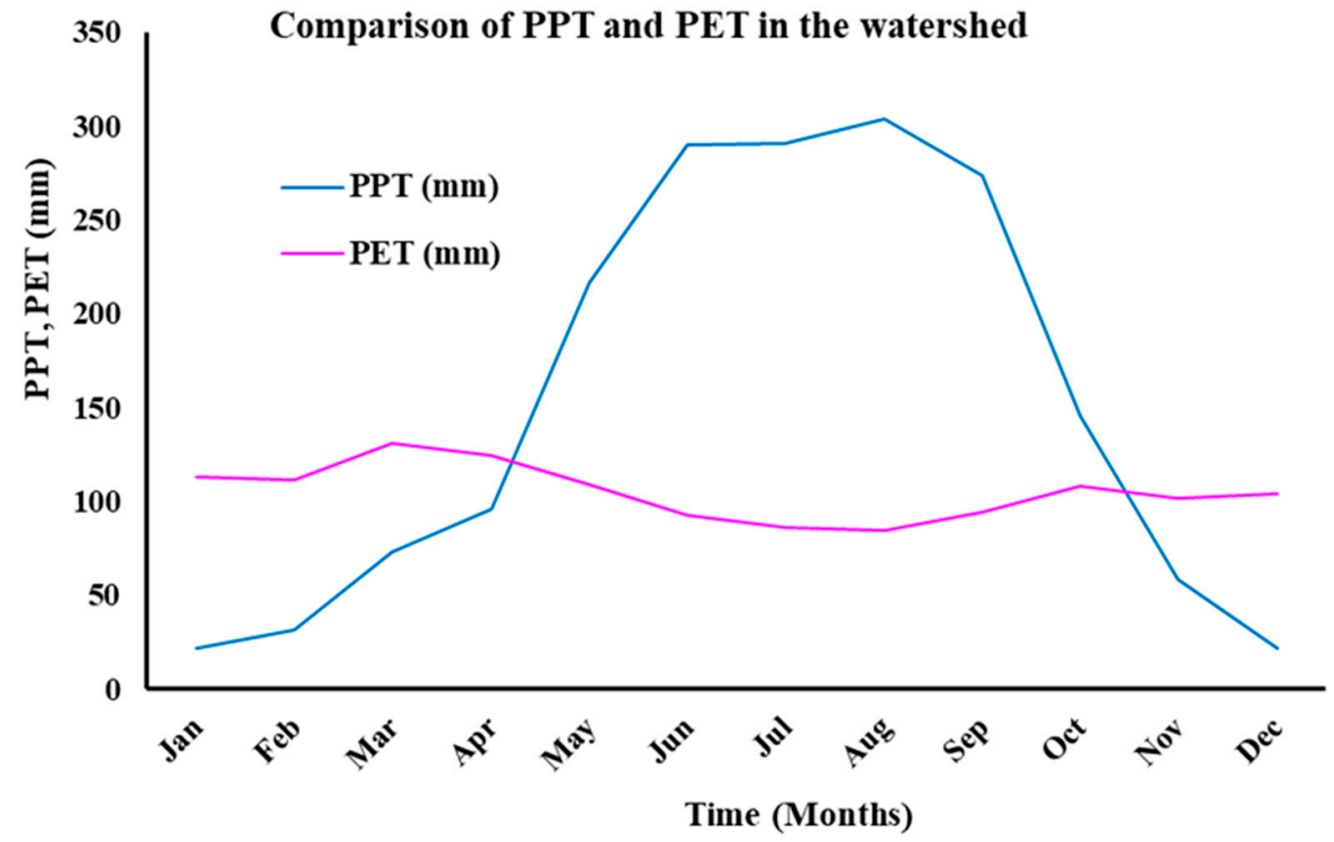

Figure 9. Long-term (1961-1990) precipitation and potential evapotranspiration (NMA and FAO LocClim database).

\subsection{Manual Hydrograph Analysis}

The time-series flow data show the streams had low flow, especially in the dry seasons, and experienced high flow during the wet seasons. The values at the bottom near the x-axis are the portion of baseflow, and the ones at the top are the portion of direct runoff (see Figure 5). The long-term mean annual flow of the two streams combined at the confluence was $138 \mathrm{~m}^{3} / \mathrm{s}$. This discharge resulted in a yearly flow of $4.35 \mathrm{BCM}$. The combined average BFI of these streams equaled $30 \%$ (Table 4 ), and this is the contribution of underground storage aquifers to streamflow at the confluence.

Table 4. Sor and Gebba average values of BFI from FDC and manual average.

\begin{tabular}{ccccccc}
\hline Watershed & Each Year Avg. & All Year Avg. & Manual Avg. & Avg. of Avg. & Area (Km $\left.{ }^{2}\right)$ & Avg. BFI \\
\hline Gebba BFI & 0.25 & 0.29 & 0.42 & 0.32 & 3894 & 1622 \\
Sor BFI & 0.18 & 0.19 & 0.35 & 0.24 & 0.30 \\
\hline
\end{tabular}


The time-series daily streamflow data comprise a lot of information. Baseflow is a continuous flow throughout the year emerging from the underground storage aquifers to sustain the streamflow. However, direct runoff happens every wet season. The mean monthly baseflow estimate using the manual hydrograph analysis method from 30 years of continuous flow data is shown in Table 5 below. Streamflow at the outlet of the watershed can be represented by the following equation:

$$
D R+R e c h+D G W=Q_{0}
$$

where $D R$ is direct runoff; Rech is aquifer recharge; $D G W$ is contribution of the deep groundwater.

$$
\% \text { Rech }+D G W=\text { Contribution from groundwater }
$$

\begin{tabular}{|c|c|c|c|c|}
\hline $\begin{array}{l}\text { Excess Rainfall, } d \\
(\mathrm{~mm})\end{array}$ & $\begin{array}{c}\mathrm{DR}+\mathrm{Rech}=d * A \\
(\mathrm{BCM})\end{array}$ & $\begin{array}{l}30 \% \text { Aquifer Rech } \\
\text { (BCM) }\end{array}$ & $\begin{array}{c}\text { Flow@ Confluence } \\
\text { (BCM) }\end{array}$ & $\begin{array}{c}\text { Contribution from } \\
\text { GW (BCM) }\end{array}$ \\
\hline 560 & 3.67 & 1.1 & 4.35 & 1.78 \\
\hline 272 & \multicolumn{3}{|c|}{$\%$ of baseflow to total streamflow $1.78 / 4.35$} & 0.41 \\
\hline
\end{tabular}

Table 5. Baseflow contribution estimated from precipitation.

Mean monthly streamflow data were applied for manual separation of the baseflow from the direct surface runoff. The data used in this study were included from the years 1986 to 2015. As shown on the hydrograph of the average monthly flow data, the annual average flow of Sor near Metu and Gebba near Suphe were 51 and 59 Cumecs. The baseflow estimated for the Sor and Gebba streams were 18 and 25 Cumecs. The baseflow contribution ratios for Sor and Gebba streams were 0.35 and 0.42 (Figure 10). This ratio gives a value of $40 \%$ for the entire watershed. These BFI values gave an impression of the underground storage aquifer's contribution to the streams. The baseflow contribution of both streams is significant and comparable to the baseflow estimated from precipitation, i.e., $41 \%$.
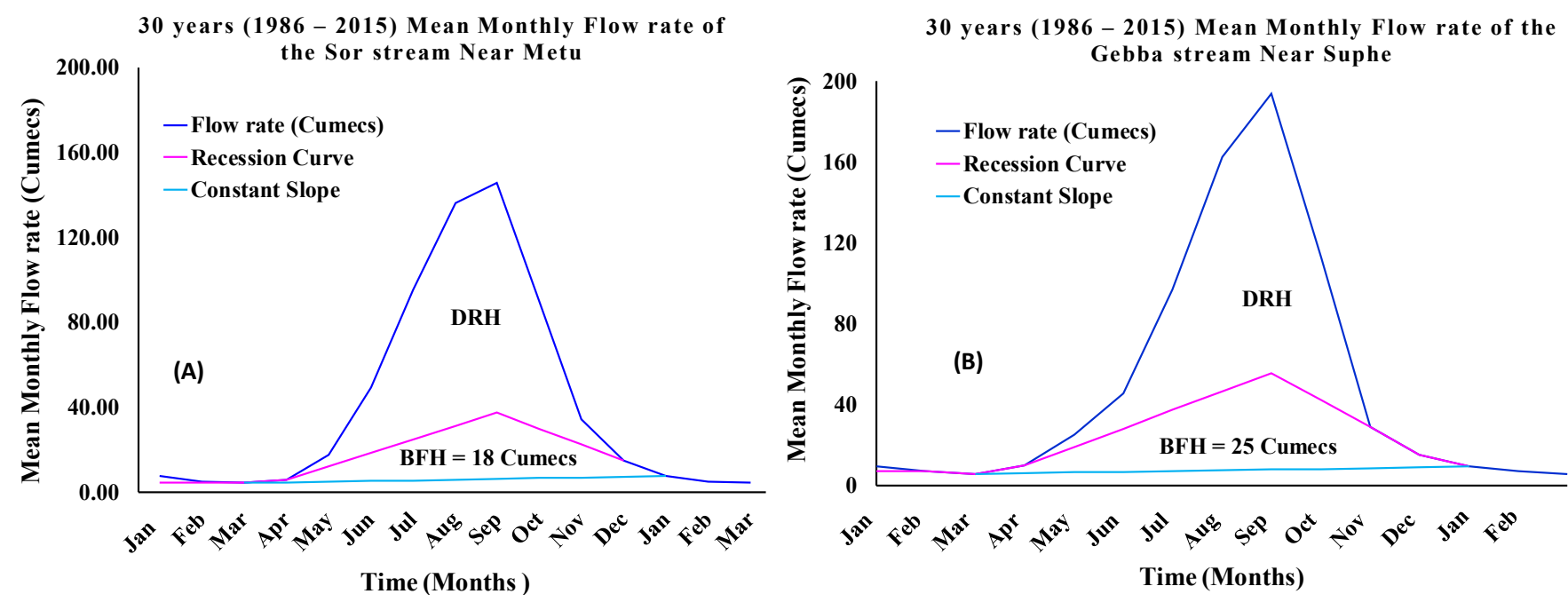

Figure 10. Manual hydrograph analysis from 30 years average monthly flow for (A) Sor stream and (B) Gebba stream.

\subsection{FDC and BFI}

Analysis of the FDC on the basis of daily streamflow data using Q90/Q50 ratio (Figure 11) provided 0.18 and 0.25 for the Sor and the Gebba streams, respectively. This ratio indicates that the underground storage aquifer's contribution to the Sor stream is relatively lower than that of the Gebba stream. The ratios of $18 \%$ and $25 \%$ are lower 
compared to the one calculated by the manual hydrograph analysis from the precipitation and streamflow. This ratio gave a value of $23 \%$ for the entire watershed.

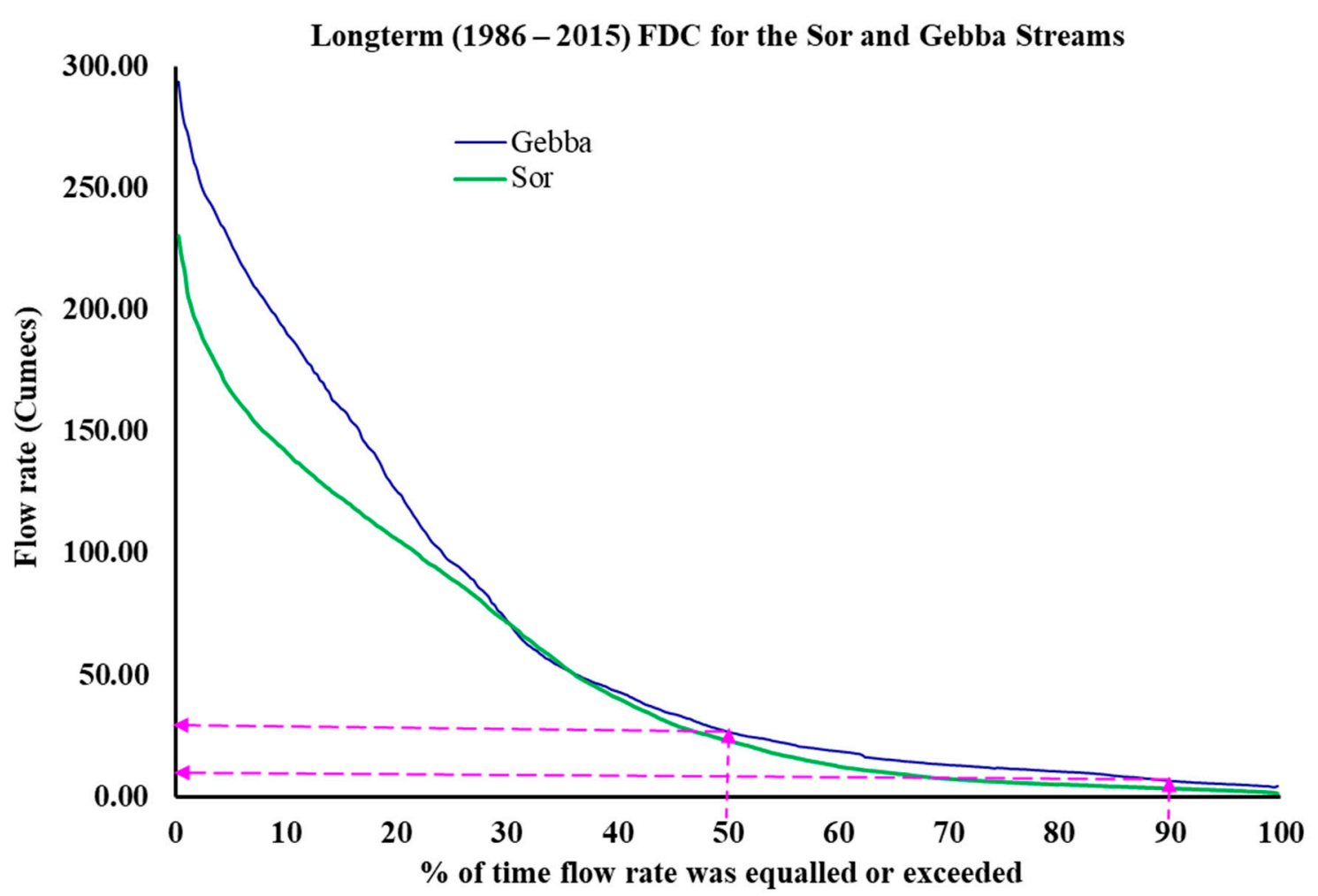

Figure 11. FDCs for measured data of Sor near Metu and Gebba near Suphe from 1986-2015.

The long-term ratio of baseflow to streamflow or the BFI equals the Q90/Q50 ratio representing an outflow of the groundwater or other delayed sources to the streamflow. Hydraulic structures constructed upstream of the hydrologic gauging stations can affect the flow conditions. Fortunately, there have not been streamflow control, regulation, and diversion structures built upstream of these two hydrological gauging stations. These BFI values relate to the geology and hydrogeology of the watershed. Concerning the discrepancy in the result, it is worth noting that there are denser geologic structures in the Gebba than in the Sor watershed. The ratio of Q90/Q50 is in a general annual declining trend for both streams showing the contribution from groundwater reduced from year to year. The primary reason for the decline could be the land-use changes.

\subsection{Automated Baseflow Separation}

An automated spreadsheet model developed by Gabriel Parodi, having the basis of signal analysis proposed and described by [54] and [3], brings a good use of visualizing the output of the one-parameter filter. A maximum value recommended for $\alpha$ equals 0.995 , and this gave BFI values of 0.63 and 0.60 for the Sor and the Gebba streams (Figures 12-17). This spreadsheet model uses each year's daily flow data for the hydrograph analysis and baseflow separation. The baseflow separation model involved average precipitation values. 


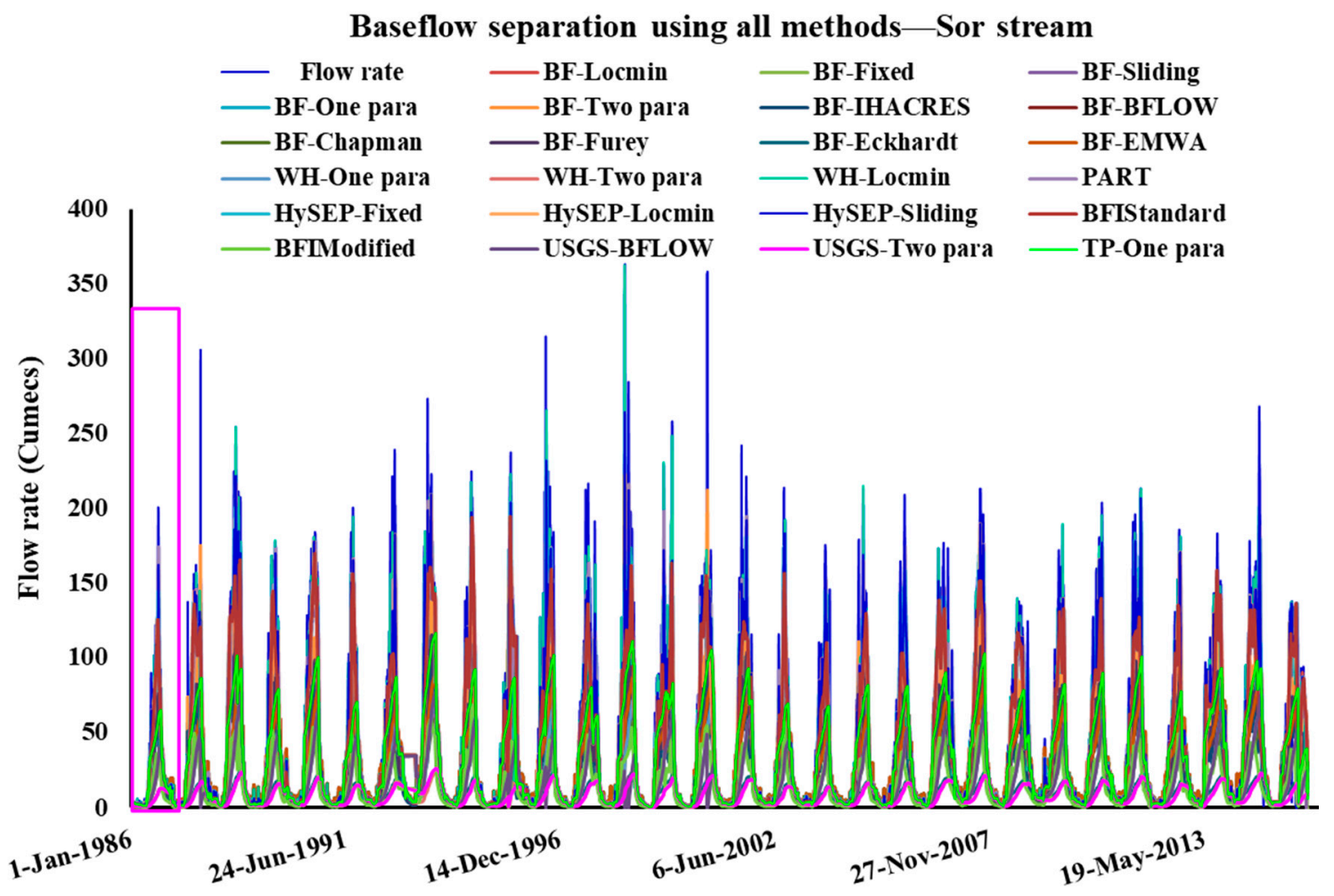

Time (Days)

Figure 12. Baseflow separation using all automated methods for the Sor stream. (Results of all methods are displayed together. The figure is compacted and difficult to understand. Therefore, a detailed one-year baseflow separation result is shown in Figure 13. Each technique is further singled out and plotted in Figure 14. The following abbreviations were used for the summarized programs: BF is BFI+; USGS is USGS GW Toolbox; WH is WHAT; TP is timeplot and encircled as an example in Figure 14 for parameters, One para is one parameter, and Two para is two parameter).

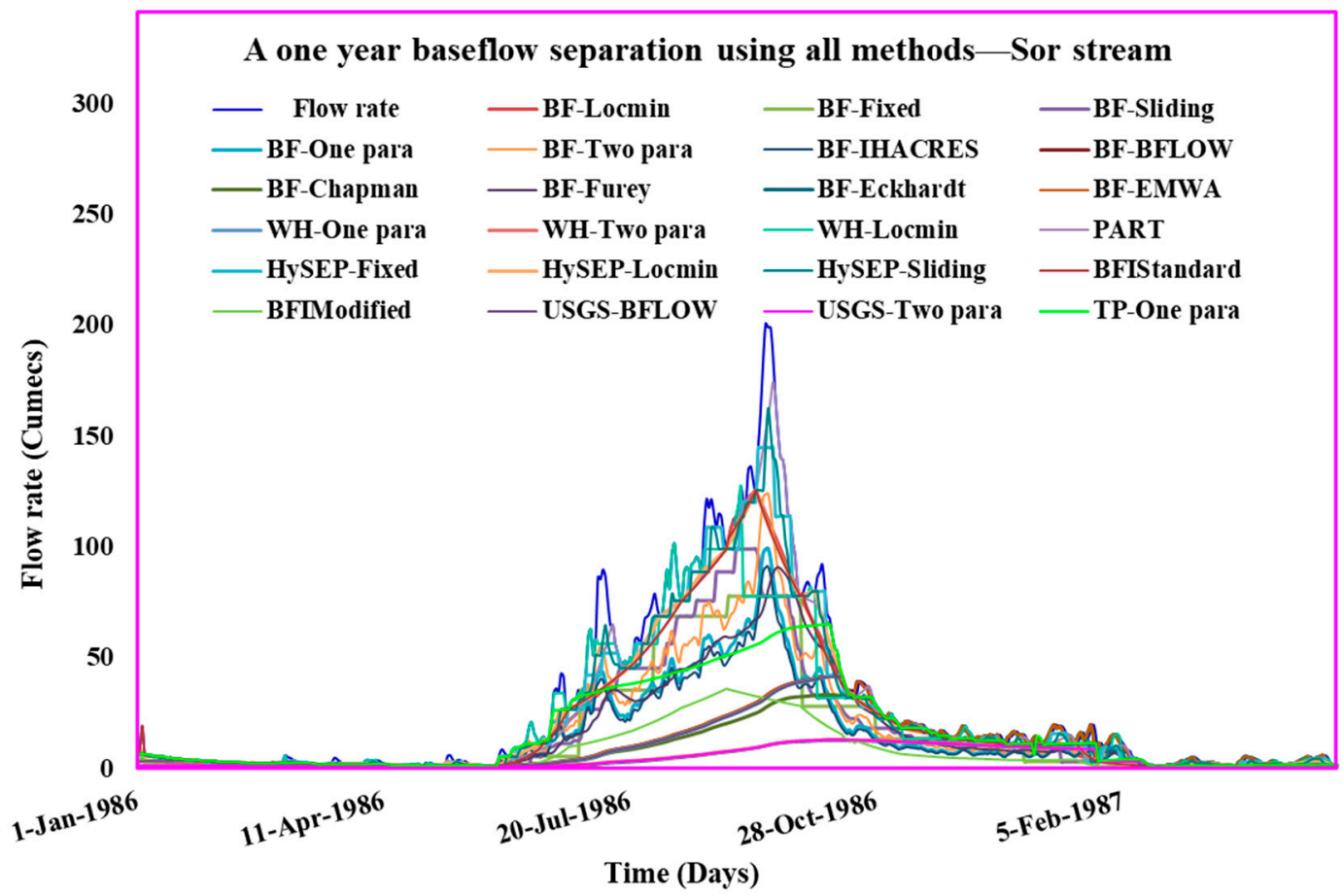

Figure 13. Baseflow separation using all automated methods for the Sor stream. (Results of all methods are displayed together. This figure shows a one-year baseflow separation). 

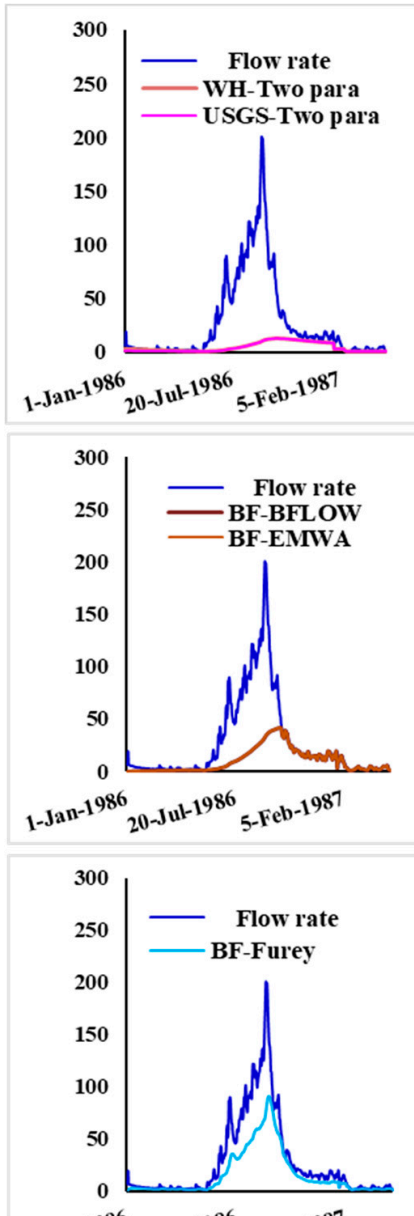

1.Jan-1986 20 -Jul-1986 5 -Feb-1987

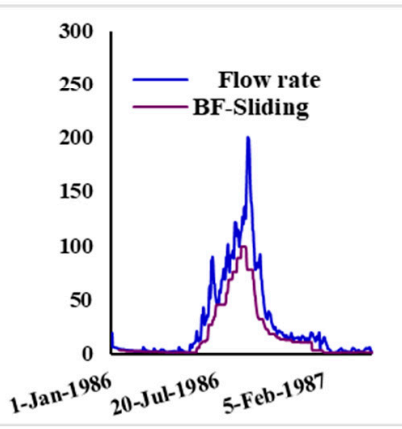

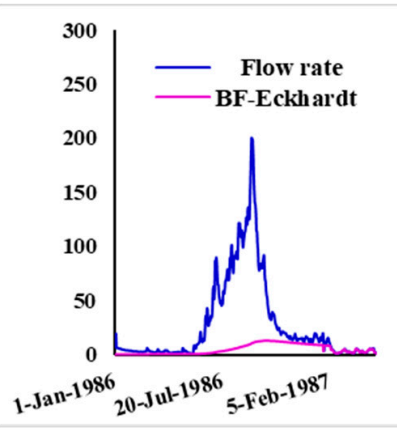
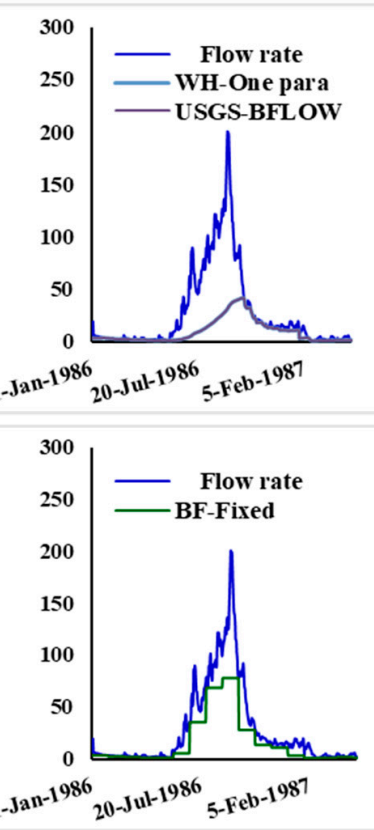

1.Jan-1986 $20-J u l-1986$ 5- Feb-1987

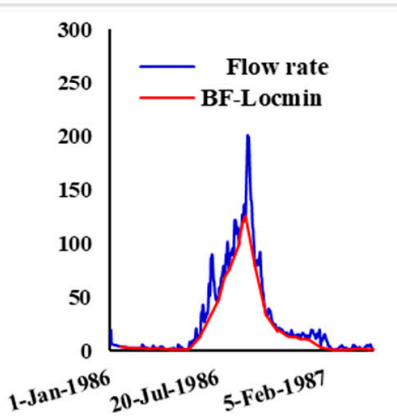

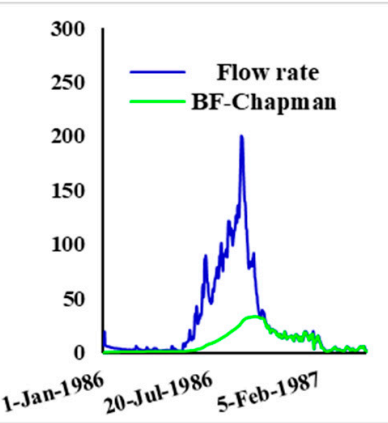
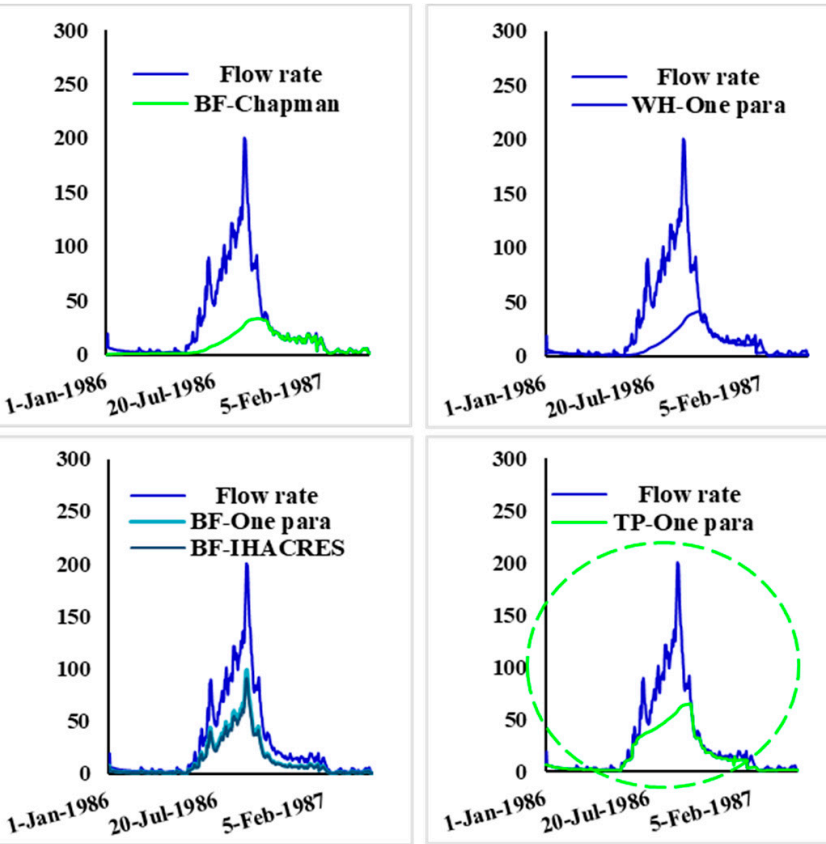

1-Jan-1986 $20-J u t-1986$ - Feb-1987
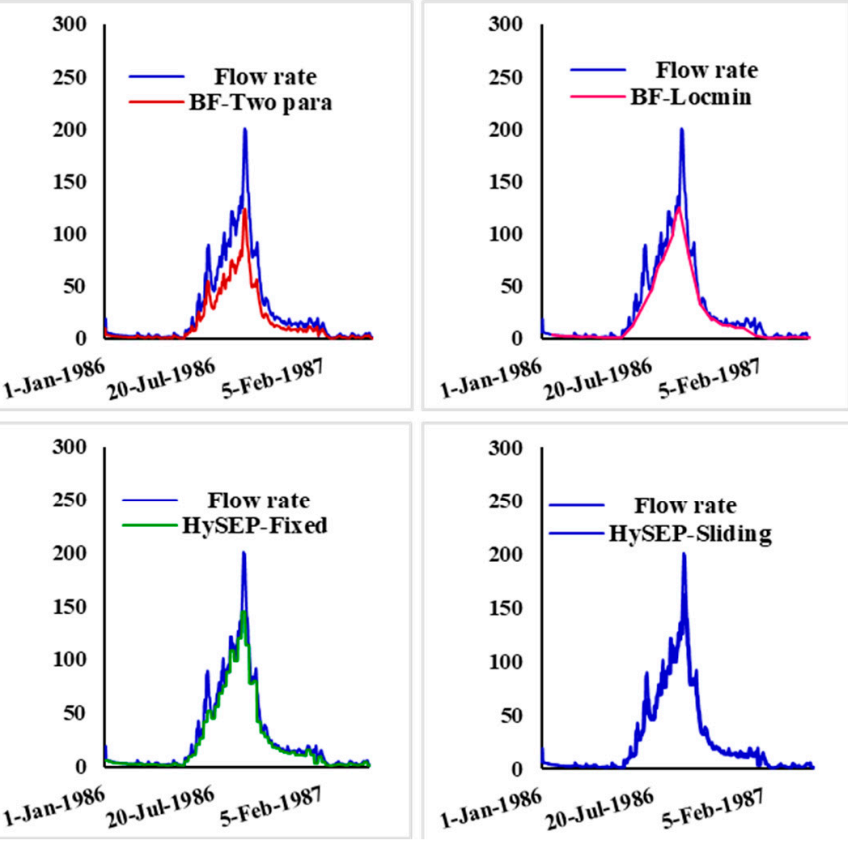

Figure 14. Baseflow separation (one-year) results using each automated RDF method for the Sor stream. 


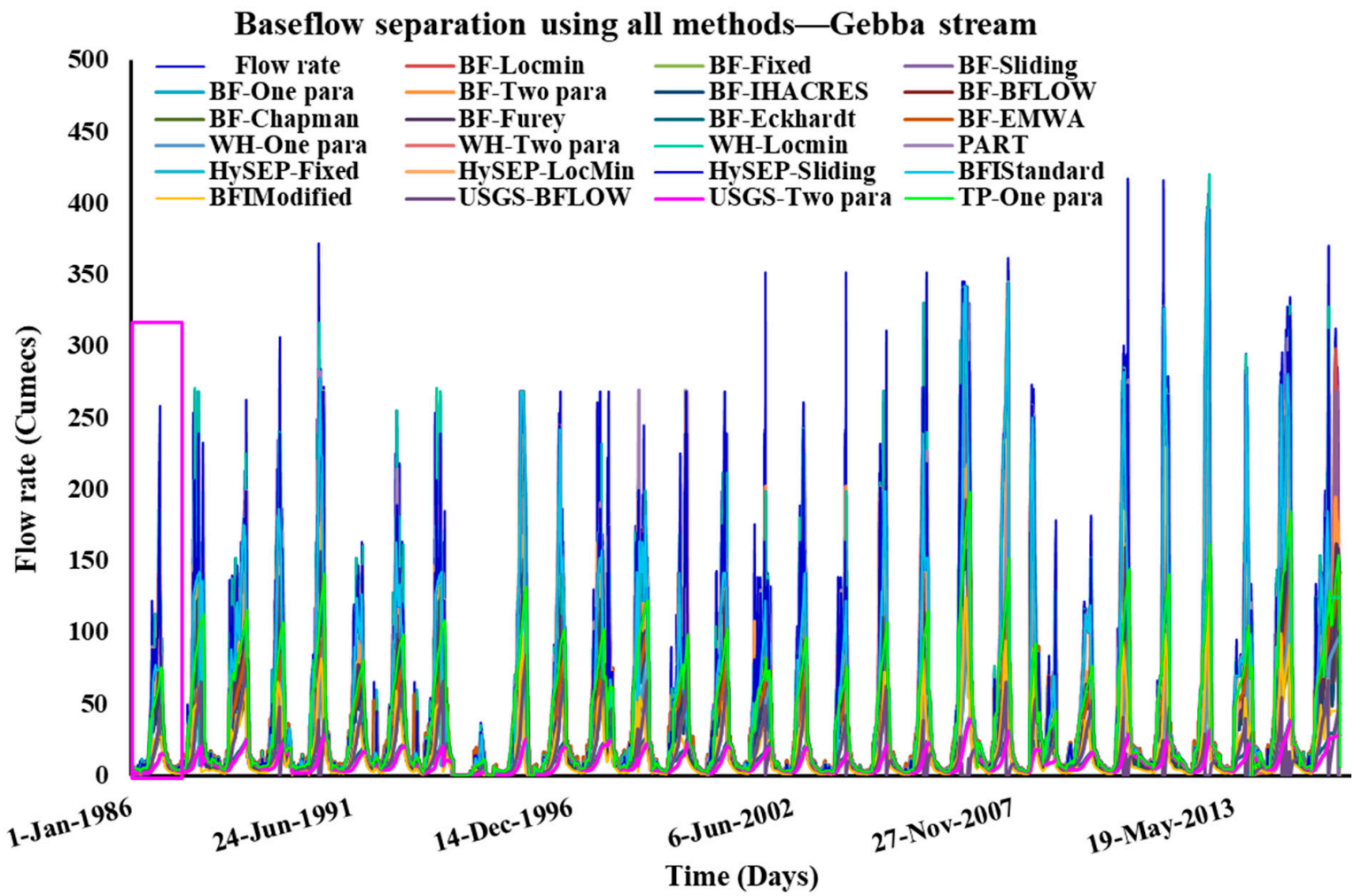

Figure 15. Baseflow separation results using all automated methods for the Gebba stream (all methods are drawn together. The figure is compacted and difficult to understand. Therefore, a detailed one-year baseflow separation result is displayed in Figure 16. The graph of each technique is shown in Figure 17).

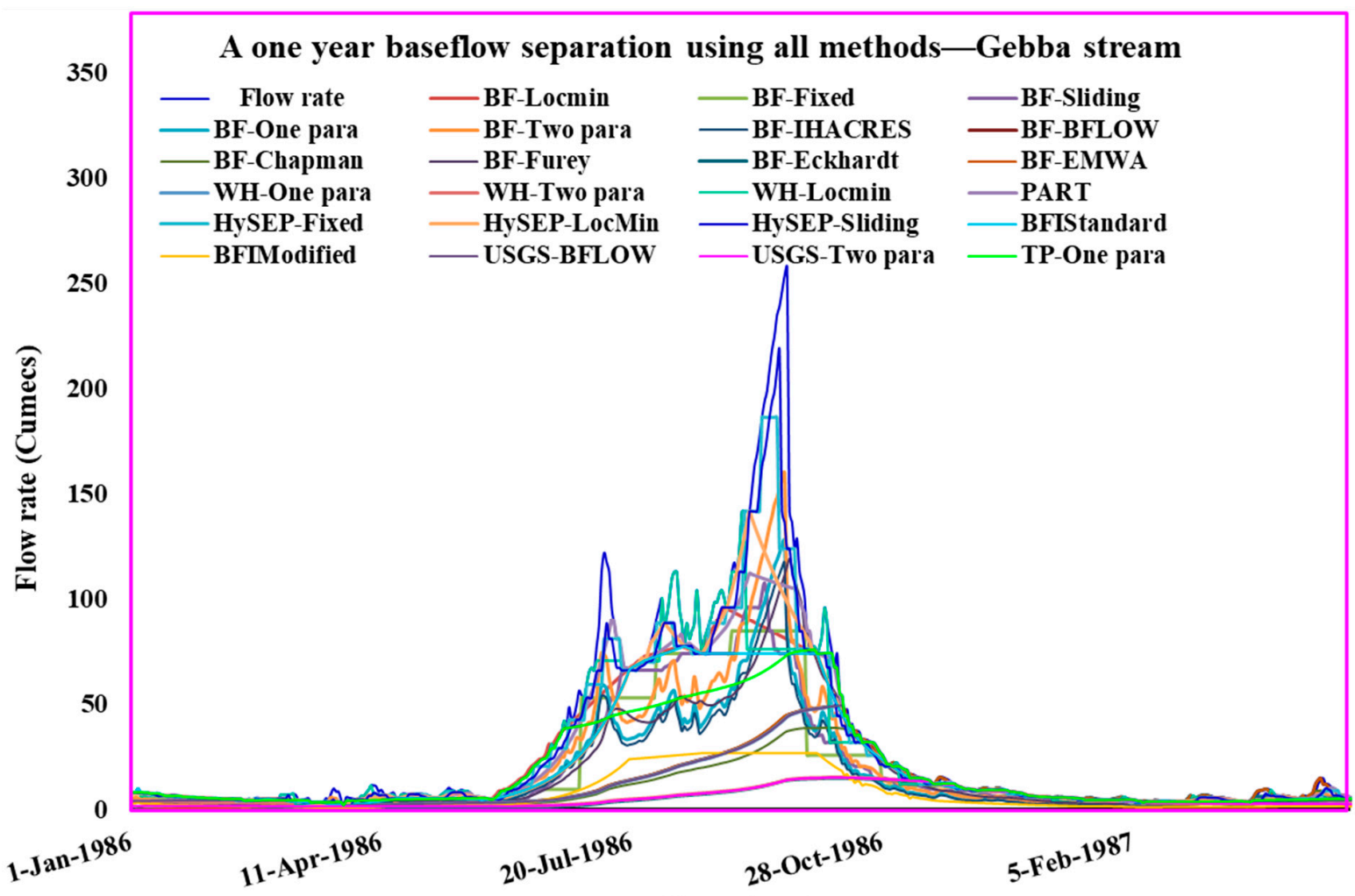

Time (Days)

Figure 16. Baseflow separation using all automated methods for the Gebba stream. (Results of all methods are displayed together. This figure shows a one-year baseflow separation). 


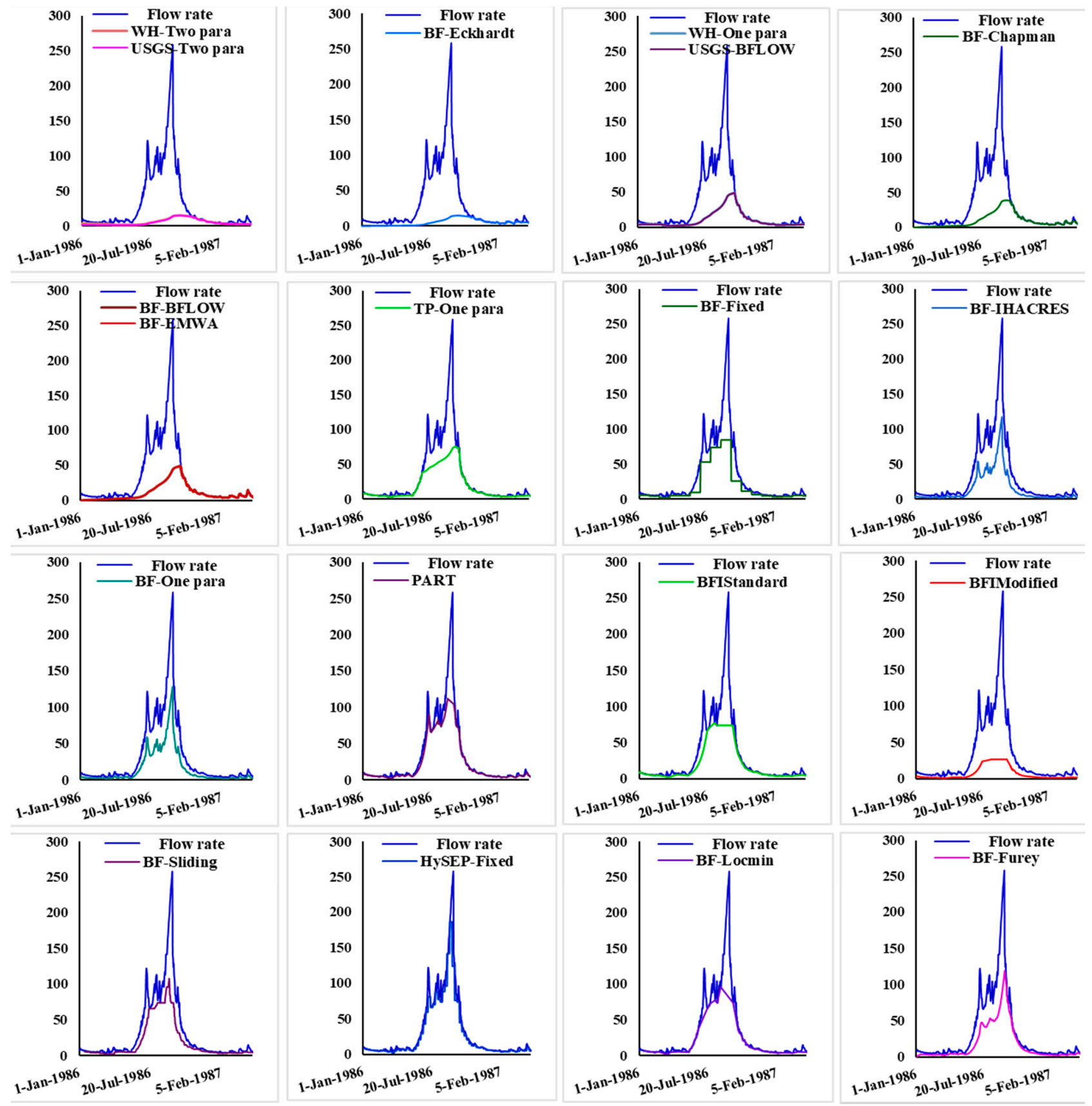

Figure 17. Baseflow separation (one-year) using each automated RDF method for the Gebba stream.

\subsection{Baseflow Separation Using RDF}

The WHAT automated digital filtering tool helped with baseflow separation. It receives Tab, comma, space-delimited ".csv" file formats. Therefore, it needs to prepare the data according to these formats. The tool accepts the entire data once and analyzes the data using all three methods. It has been widely used for baseflow separation on a longterm basis using the two-parameters $\left(\alpha\right.$ and $B F I_{\max }$ ) digital filtering. These two parameter filtering techniques, Bflow and Eckhardt, provide smooth time-series of baseflow. A $B F I_{\max }$ value of 0.25 for Perennial streams with hard rock aquifers and a filter parameter, $\alpha$ value of 0.995 , were used for the Sor and the Gebba streams. The BFI value is comparable with the FDC and the manual baseflow separation obtained using the one parameter and the two-parameter digital filter methods (Figures 12-20). 


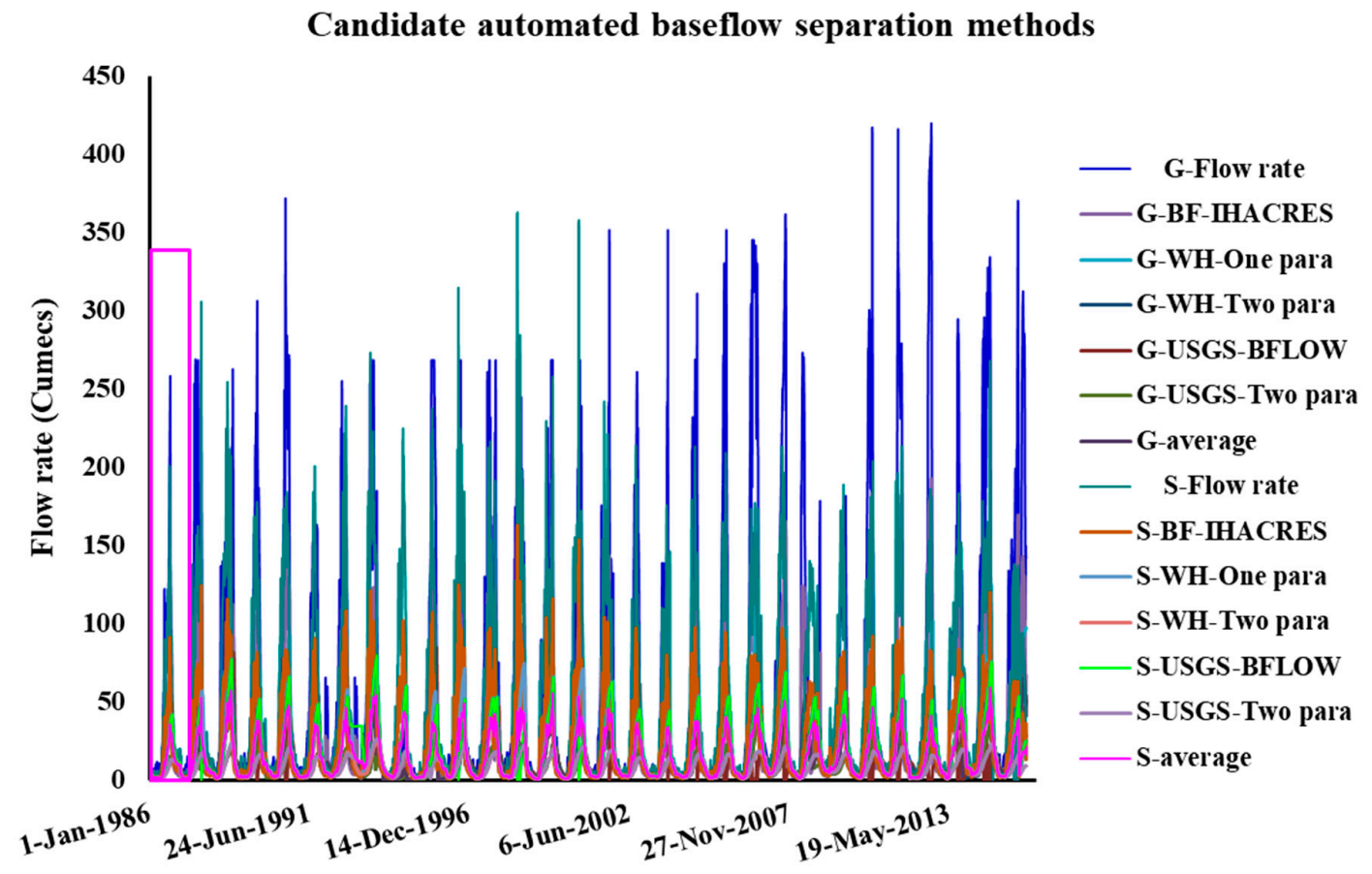

Time (Days)

Figure 18. All candidate automated methods for use in the Sor and Gebba streams (Note: $S$ is Sor, and G is Gebba). (The figure is compacted and difficult to understand. Therefore, a detailed one-year baseflow separation result is displayed in Figure 19. The graph of each technique is shown in Figure 20).

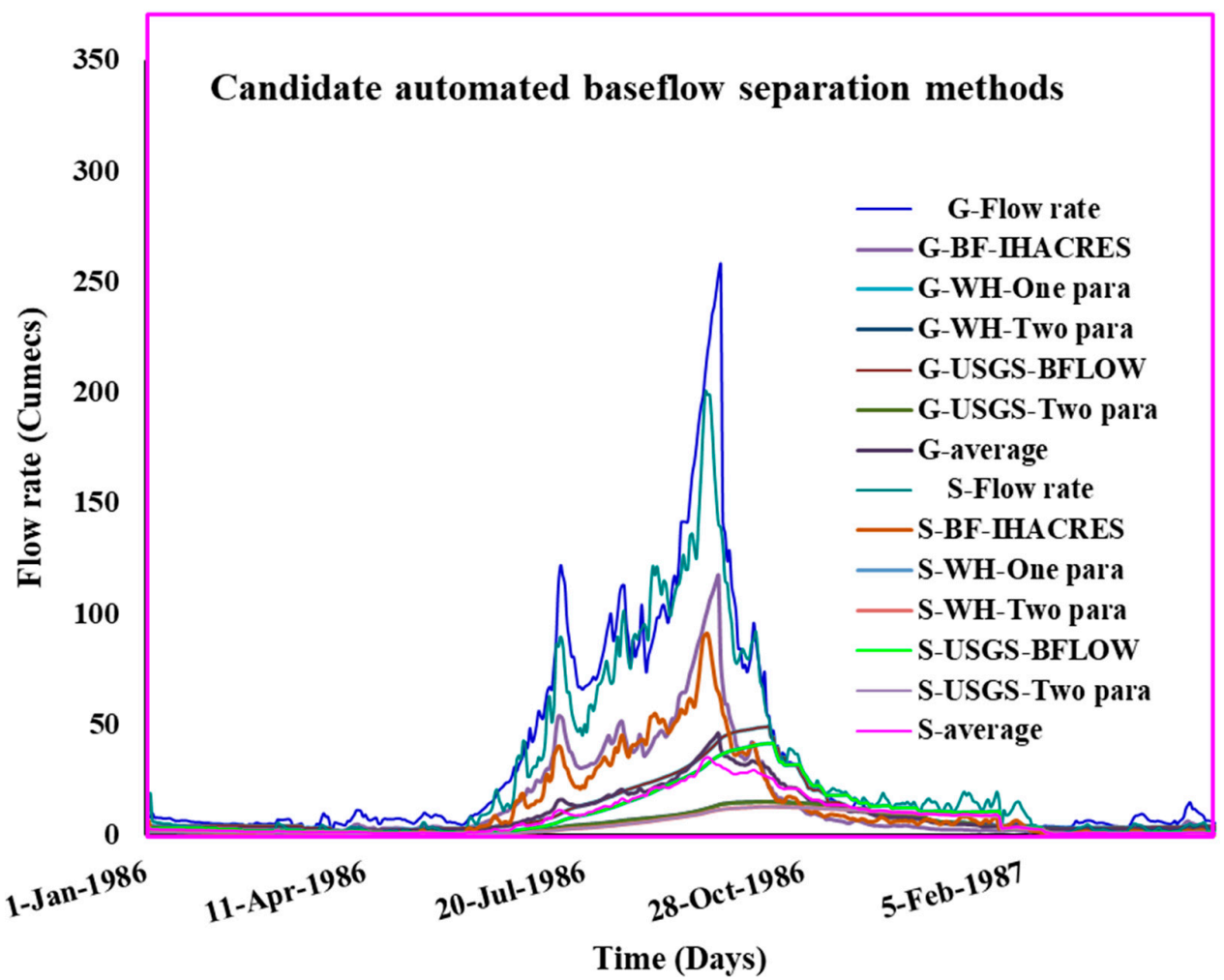

Figure 19. Baseflow separation using all candidate methods for both streams. (Results of all candidate methods are displayed together. This figure shows a one-year baseflow separation). 
An evaluation of all the eight USGS GW Toolbox results was carried out. HYSEP (fixed interval, local minimum, and sliding interval), and PART provided higher values of baseflow estimates. The BFI-modified, one-parameter, two-parameter, and BFI standard methods reasonably estimated the baseflow as a ratio of baseflow index ranging from 0.27 to 0.45 .
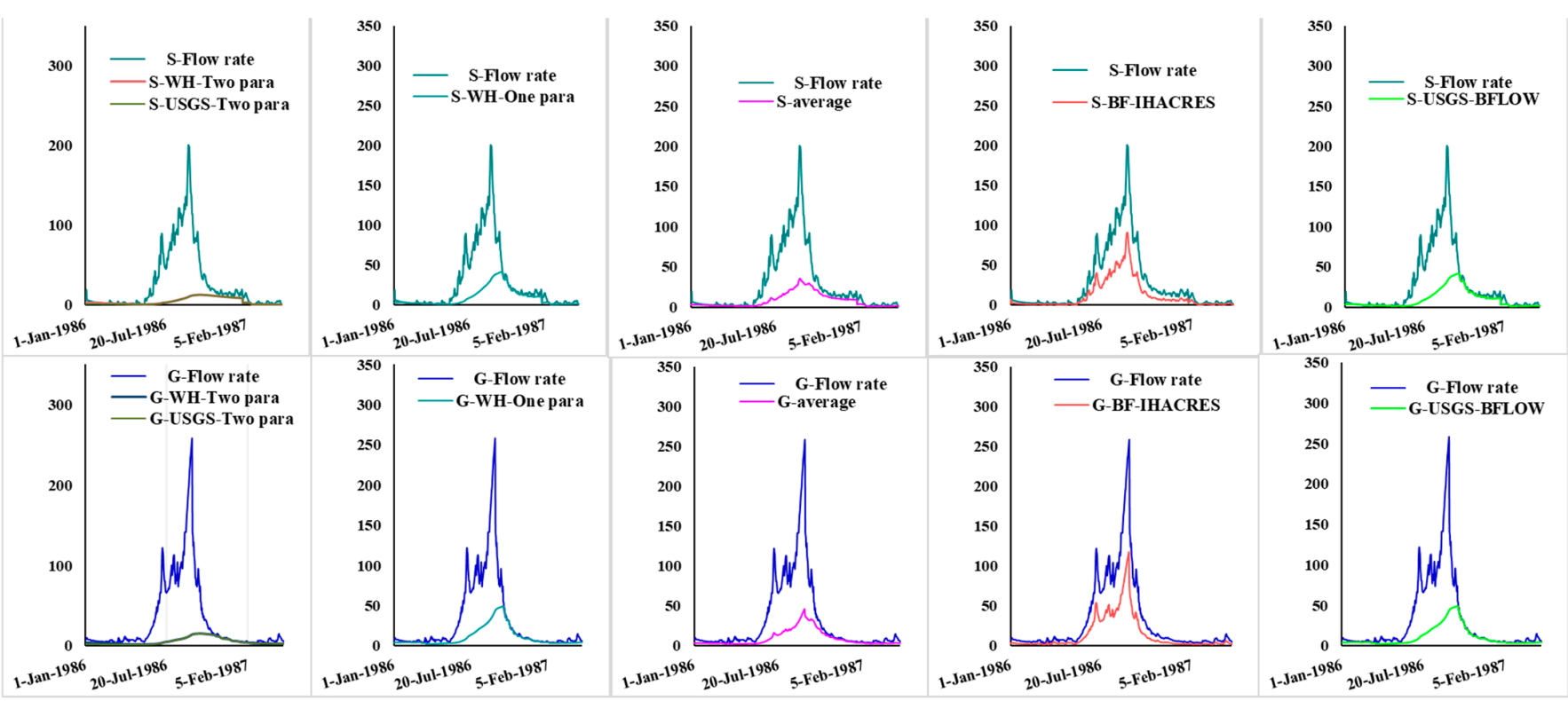

Figure 20. Each candidate method results for use in the Sor and Gebba streams (Note: S is Sor, and G is Gebba).

For the fixed interval and sliding interval methods, $N$ equals 30 days. In the RDF, the recession constant, $k$ equals 0.4 , the filter parameter, $\alpha$ equals 0.995 , the $C$ value equals $0.995, C_{1}$ and $C_{2}$ in the Furey and Gupta Algorithm are 0.1 and $0.13, \gamma$ equals 0.05, and $B F I_{\text {max }}$ equals 0.25 applied (Figures 18 and 20 and Table 6).

In the local minimum method of the HydroOffice program (BFI+), the default turning point parameter $(f)$ equaled 0.9 and determined whether the minimum was identified as a local minimum and the separating value or streamflow minimum in consecutive periods of $N$ equals five days. The default values $f$ equaled 0.9 , and $N$ equaled five used. Milos Gregor [62] stated the baseflow hydrograph is more sensitive to changes in the parameter $N$ than changes in the turning point parameter $f . N$ will only vary between roughly two and five days for catchment areas between 100 and $10,000 \mathrm{~km}^{2}$, since $N=0.83 A^{0.2}$.

RDF developed by Milos Gregor analyzes the same data using all eleven techniques. Based on the two-parameter recursive digital filter Eckhardt's equation given in equation (7) above, an alpha $(\alpha)$ value of 0.995 and using a $B F I_{m a x}$ value of 0.25 for the Sor and the Gebba resulted in higher values when compared to the manual baseflow separation and the flow duration analysis. Based on the single parameter filter equation, the $\alpha$ value of 0.995 does better for both the Sor and Gebba streams. Hydrological data enables the separation of baseflow from the streamflow. Subsequently, fixing the filter parameters for each method, the model ran and acquired results. The results of baseflow from BFI+ were above streamflow average for all techniques except the RDF-IHACRES, which gave reasonable outputs. However, the RDF one parameter and Eckhardt algorithm provided fair results.

By applying all the twenty-five methods, the range of values of groundwater contribution to the Sor and Gebba streams was between $15 \%$ and $85 \%$, having an average value of $56 \%$. However, the FDC and manual average showed a BFI value of less than average (Table 6 and Figure 21A). Taking the average of all BFI values from all methods resulted less than average gave an overall average of $33 \%$, which is a better estimate for the entire 
watershed. In this regard, the RDF (one parameter and two-parameter), the IHACRES, and BFI modified methods estimated better for the total watershed (Table 7).

Table 6. Summary of used parameters and BFI values from all baseflow separation techniques.

\begin{tabular}{|c|c|c|c|c|c|}
\hline S. No & $\begin{array}{c}\text { Hydrograph Separation } \\
\text { Method }\end{array}$ & Parameters Used & $\begin{array}{l}\text { BFI Values for } \\
\text { Sor }\end{array}$ & $\begin{array}{l}\text { BFI Values for } \\
\text { Gebba }\end{array}$ & Avg. BFI Values \\
\hline I & FDC & Q90/Q50 & 0.18 & 0.25 & 0.23 \\
\hline II & Manual Avg. & Recession curve and Graph & 0.35 & 0.42 & 0.40 \\
\hline III & Gabriel Parodi & $\alpha=0.995$ & 0.63 & 0.60 & 0.61 \\
\hline IV & WHAT & & & & \\
\hline 1 & WH-Locmin & $f=0.9, N=5$ & 0.85 & 0.85 & 0.85 \\
\hline 2 & WH-One para & $\alpha=0.995$ & 0.35 & 0.33 & 0.34 \\
\hline 3 & WH-Two para & $B F I_{\text {max }}=0.25, C=0.995$ & 0.16 & 0.15 & 0.15 \\
\hline V & HydroOffice (BFI+) & Milos Gregor Model & & & \\
\hline 1 & BF-Locmin & $f=0.9, N=5$ & 0.81 & 0.86 & 0.85 \\
\hline 2 & BF-fixed & $N=30$ & 0.64 & 0.66 & 0.65 \\
\hline 3 & BF-Sliding & $N=30$ & 0.63 & 0.65 & 0.64 \\
\hline 4 & BF-One para & $k=0.4$ & 0.50 & 0.50 & 0.50 \\
\hline 5 & BF-Two para & $k=0.4, C=0.995$ & 0.63 & 0.63 & 0.63 \\
\hline 6 & BF-IHACRES & $\alpha q=0.01, C=0.5, k=0.4$ & 0.46 & 0.46 & 0.46 \\
\hline 7 & BF-BFLOW & $\alpha=0.995$ & 0.80 & 0.56 & 0.63 \\
\hline 8 & BF-Chapman & $\alpha=0.995$ & 0.67 & 0.59 & 0.61 \\
\hline 9 & BF-Furey & $\begin{array}{c}C_{1}=0.1, C_{2}=0.13, g=0.05 \\
d=2 \text { days }\end{array}$ & 0.62 & 0.60 & 0.61 \\
\hline 10 & BF-Eckhardt & $\alpha=0.995, \mathrm{BF}_{\max }=0.25$ & 0.55 & 0.58 & 0.57 \\
\hline 11 & BF-EWMA & $\alpha=0.005$ & 0.80 & 0.80 & 0.81 \\
\hline VI & USGS GW Toolbox & & & & \\
\hline 1 & HYSEP-Fixed & $N=30$ & 0.64 & 0.66 & 0.65 \\
\hline 2 & HYSEP-Locmin & $f=0.9, N=5$ & 0.82 & 0.83 & 0.83 \\
\hline 3 & HYSEP-Sliding & $N=30$ & 0.63 & 0.65 & 0.64 \\
\hline 4 & PART & & 0.83 & 0.86 & 0.85 \\
\hline 5 & USGS-One para & $\alpha=0.995$ & 0.35 & 0.31 & 0.32 \\
\hline 6 & USGS-Two para & $\alpha=0.995, \mathrm{BF}_{\max }=0.25$ & 0.37 & 0.48 & 0.45 \\
\hline 7 & BFI-Standard & $k=0.9, N=5$ & 0.54 & 0.51 & 0.52 \\
\hline \multirow[t]{4}{*}{8} & BFI-Modified & $k^{\prime}=0.995, N=30$ & 0.38 & 0.22 & 0.27 \\
\hline & & $\min$ & 0.16 & 0.15 & 0.15 \\
\hline & & $\max$ & 0.85 & 0.86 & 0.85 \\
\hline & & avg & 0.57 & 0.56 & 0.56 \\
\hline
\end{tabular}
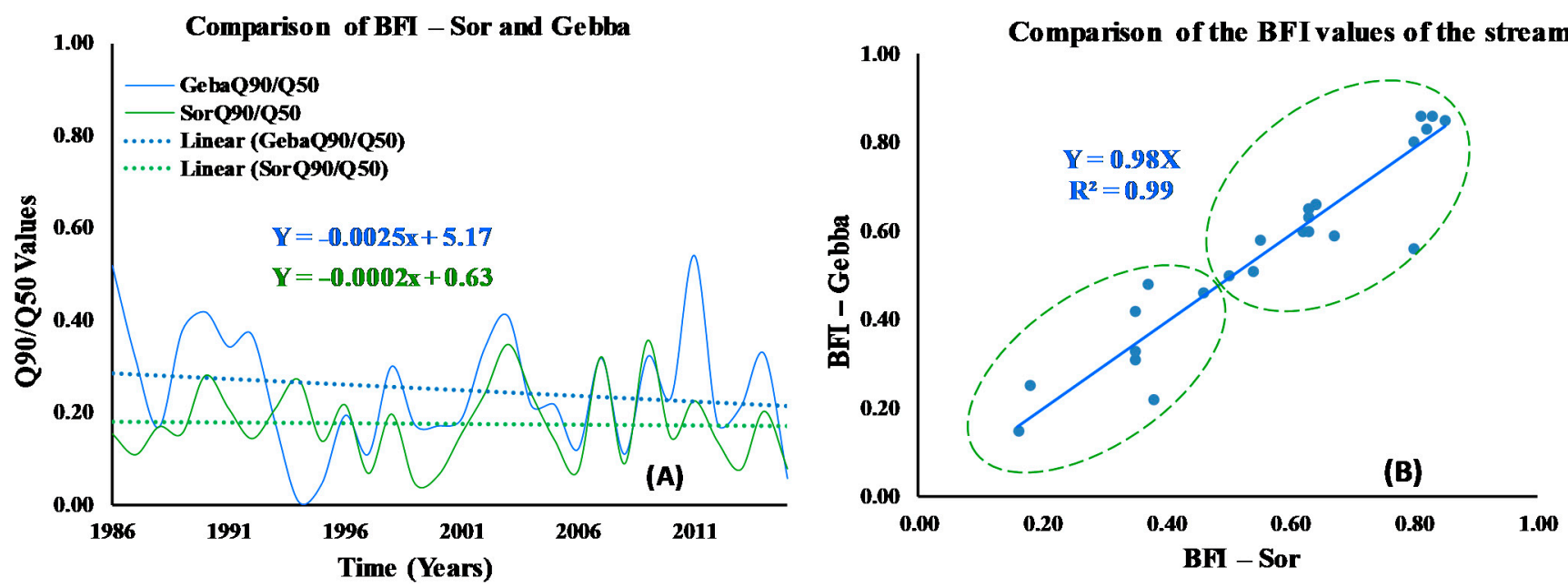

Figure 21. Comparison of the Sor and Gebba streams. (A) BFI from FDC, (B) BFI of all methods. 
Table 7. Summary of methods, parameters, and BFI values for selected baseflow separation techniques.

\begin{tabular}{|c|c|c|c|c|c|}
\hline S. No & $\begin{array}{c}\text { Hydrograph Separation } \\
\text { Method }\end{array}$ & Parameters Used & $\begin{array}{l}\text { BFI Values for } \\
\text { Sor }\end{array}$ & $\begin{array}{l}\text { BFI Values for } \\
\text { Gebba }\end{array}$ & Avg. BFI Values \\
\hline I & FDC & Q90/Q50 & 0.18 & 0.25 & 0.23 \\
\hline II & Manual Avg. & Recession curve and graph & 0.35 & 0.42 & 0.40 \\
\hline III & WHAT & & & & \\
\hline 1 & RDF-One parameter & $\alpha=0.995$ & 0.35 & 0.33 & 0.34 \\
\hline 2 & RDF-Two parameters & $B F I_{\max }=0.25, C=0.995$ & 0.16 & 0.15 & 0.15 \\
\hline IV & HydroOffice & Milos Gregor model & & & \\
\hline 1 & RDF-IHACRES & $\alpha q=0.01, C=0.5, k=0.4$ & 0.46 & 0.46 & 0.46 \\
\hline V & USGS GW Toolbox & & & & \\
\hline 1 & RDF-One parameter & $\alpha=0.995$ & 0.35 & 0.31 & 0.32 \\
\hline 2 & RDF-Two parameters & $\alpha=0.995, B F I_{\max }=0.25$ & 0.37 & 0.48 & 0.45 \\
\hline \multirow[t]{4}{*}{3} & BFI-Modified & $k^{\prime}=0.995, N=30$ & 0.38 & 0.22 & 0.27 \\
\hline & & $\min$ & 0.16 & 0.15 & 0.15 \\
\hline & & $\max$ & 0.46 & 0.48 & 0.46 \\
\hline & & avg & 0.33 & 0.33 & 0.33 \\
\hline
\end{tabular}

\section{Conclusions}

In the Sor and Gebba watershed, direct runoff had a significant (two-third) contribution compared to baseflow. It is worth remembering that channel precipitation and interflow are parts of direct surface runoff. An analysis performed in this study identified less than average (one-third) baseflow contribution to streamflow. The lower proportion (contribution) of baseflow could be associated with the type of aquifer system (faulted, fractured, and jointed) and the rugged topography of the watershed. Geology, hydrogeology, soils, and weather variability could also contribute to the baseflow. The watershed is also a recharge zone.

As shown in Figure 21A, the negative slope $(-S)$ trend lines showed that for both the Sor and the Gebba streams, the BFI values behaved in a generally declining trend. When comparing the BFI values of the two streams (Figure 21B), a higher $\mathrm{R}^{2}$ value showed the streams have similar characteristics. On top of that, the " $\mathrm{S}$ " value less than one implies the BFI for the Sor stream was greater than the BFI for the Gebba stream. The value of " $\mathrm{S}$ " closer to one (1) indicates similar baseflow contributions to both streams from the watershed.

Twenty-five methods were applied to estimate baseflow in the Sor and Gebba streams (Table 6). These are the manual graphical hydrograph analyses: the FDC, the timeplot model, the WHAT having three models, the USGS GW Toolbox using eight tools, and the BFI+ of the HydroOffice with eleven tools. The FDC analysis showed the Q90/Q50 ratio of $18 \%$ for the Sor and $25 \%$ for the Gebba streams, and exhibited an erratic trend from year to year (Figure 21A). This ratio gives a value of $23 \%$ for the entire watershed. Seventeen methods overestimated the baseflow. The fixed interval, local minimum, sliding interval, one parameter, and two-parameter filter techniques repeated themselves in other models. BFLOW in the USGS GW Toolbox was equivalent to one parameter in WHAT, and two parameters in WHAT and in USGS GW Toolbox were the same shown in Figures 17 and 20. Eight out of twenty-five methods performed better for the watershed baseflow estimation (Table 7). These were the FDC, manual average, one parameter and two parameters (WHAT and USGS GW Toolbox), the IHACRES, and BFI (modified).

Based on RDF (one parameter), the baseflow estimate equaled the direct runoff value. The reasonable BFI value for the Sor and Gebba watershed is in one of the two encircled groups shown in Figure 21B. The first group on the top-right in the figure includes local minimum, fixed interval, sliding interval, RDF (BFLOW, EWMA, the Gabriel Parodi, Chapman, Furey and Gupta algorithm), and PART. These methods overestimated the BFI values. The second group in the lower left bottom comprises FDC, manual graphical hydrograph analysis, RDF (one parameter, two parameters, and IHACRES), and BFIModified, which estimated less than average BFI values. The ones estimating the BFI values above average were suitable for porous aquifers. For hard rock aquifers similar 
to the Sor and Gebba watershed, the BFI values less than average seem to be reasonable. This second group gave an average value of 0.33 of the groundwater contributions to the Sor and Gebba streams. This ratio also provided a 33\% baseflow contribution for the entire watershed.

Several studies are essential for groundwater resource problems of the watershed in the future. Groundwater and surface water interaction and pollution problems, stream water quality management, estimating groundwater potential using other techniques, and estimating groundwater contribution under climate change are some of them to mention. We hope the output of this study will also contribute to the water resources planning, development, and management practices of the Sor and Gebba watershed.

Author Contributions: This article is part of the PhD work of W.T.B., who carried out data collection, analysis, baseflow separation, and article preparation; S.W. supervised the work, provided technical advice, examined the results, and performed general editing; M.M. comprehensively edited and critically reviewed the article; T.A. advised from inception to using automated methods. All authors have read and agreed to the published version of the manuscript.

Funding: We gratefully acknowledge the financial support from the German Academic Exchange Service (DAAD) sponsored by the EECBP Home Grown PhD Scholarship Program, 2018 (Grant No. 57399471) for the first author. The funding also comes from the Ethiopian government Ministry of Science and Higher Education. The financial support is greatly appreciated.

Institutional Review Board Statement: Not applicable.

Informed Consent Statement: Not applicable.

Data Availability Statement: The data presented in this study is available upon request from the corresponding author according to the MDPI Research Data Policies.

Acknowledgments: We acknowledge the support by the Open Access Publication Funds of the Ruhr-Universität Bochum. We would also like to thank the anonymous reviewers for their valuable comments on the previous versions of the manuscript.

Conflicts of Interest: The authors declare that they have no conflict of interest.

\section{References}

1. Indarto; Novita, E.; Wahyuningsih, S. Preliminary Study on Baseflow Separation at Watersheds in East Java Regions. Agric. Agric. Sci. 2016, 9, 538-550. [CrossRef]

2. Viessman, G.L.L.W. Introduction to Hydrology, 4th ed.; Prentice Hall: Upper Saddle River, NJ, USA, 1989; Volume 53, ISBN 9788578110796.

3. Nathan, R.J.; McMahon, T.A. Evaluation of automated techniques for base flow and recession analyses. Water Resour. Res. 1990, 26, 186. [CrossRef]

4. Pukh Raj Rakhecha, V.P.S. Applied Hydrometeorology; Capital Publishing Company: New Delhi, India, 2009; Volume 53, ISBN 9788578110796.

5. Winter, T.C.; Harvey, J.W.; Lehn Franke, O.; Alley, W.M. Groundwater and surface water: A single resource. U.S. Geological Survey Circ. 1139 1998, 17, 37-41.

6. Boussinesq, J. Recherches theoretique sur l'ecoulement des nappes d'eau infiltrees dans le sol et sur le debit des sources. Pure Appl. Maths 1904, 41, 1-8. [CrossRef]

7. Maillet, E. Essais d'hydraulique souterraine et fluviale. Nature 1905, 72, 25-26.

8. Horton, R.E. The Rôle of infiltration in the hydrologic cycle. AGU 1933, 53, 1689-1699. [CrossRef]

9. Hall, F.R. Base-Flow Recessions-A Review. Water Resour. Res. 1968, 4, 973-983. [CrossRef]

10. Linsley, R.K.; Kohler, M.A.; Paulhus, J.L.H. Hydrology for Engineers, 3rd ed.; McGraw-Hill: New York, NY, USA, 1982; ISBN 9780070379565.

11. Zecharias, Y.B.; Brutsaert, W. Recession Characteristics of Groundwater Outflow and Base Flow from Mountainous Watersheds. Water Resour. Res. 1988, 24, 1651-1658. [CrossRef]

12. Nathan, R.J.; McMahon, T.A. Estimating low flow characteristics in ungauged catchments. Water Resour. Manag. 1992, 6, 85-100. [CrossRef]

13. Tallaksen, L. A review of baseflow recession analysis. J. Hydrol. 1995, 165, 349-370. [CrossRef]

14. Gonzales, A.L.; Nonner, J.; Heijkers, J.; Uhlenbrook, S. Comparison of different base flow separation methods in a lowland catchment. Hydrol. Earth Syst. Sci. Discuss. 2009, 13, 34. [CrossRef]

15. Smakhtin, V.U. Low flow hydrology: A review. J. Hydrol. Hydrol. 2001, 240, 147-186. [CrossRef] 
16. Nathaniel, N. Comparative Analysis of Methods of Baseflow Separation of Otamiri Catchment. Int. J. Sci. Technol. Res. 2017, 6, 314-318.

17. Jakada, H.; Chen, Z.; Luo, M.; Zhou, H.; Wang, Z.; Habib, M. Watershed characterization and hydrograph recession analysis: A comparative look at a karst vs. non-karst watershed and implications for groundwater resources in Gaolan River basin, Southern China. Water 2019, 11, 743. [CrossRef]

18. Yang, W.; Xiao, C.; Zhang, Z.; Liang, X. Can the two-parameter recursive digital filter baseflow separation method really be calibrated by the conductivity mass balance method? Hydrol. Earth Syst. Sci. Discuss. 2020, 25, 1-27. [CrossRef]

19. Scanlon, B.R.; Healy, R.W.; Cook, P.G. Choosing appropriate techniques for quantifying groundwater recharge. Hydrogeol. J. 2002, 10, 18-39. [CrossRef]

20. Brodie, R.S.; Hostetler, S. A Review of Techniques for Analysing Baseflow from Stream Hydrographs. NZHS-IAH-NZSSS 2005, $28,13$.

21. Davidson, A. MoWE; MoWE: Ottawa, ON, Canada, 1983; p. 89.

22. Dingman, S.L. Fluvial Hydraulics; Oxford University Press, Inc.: New York, NY, USA, 2009; Volume 91, ISBN 9788578110796.

23. Permatasari, R.; Sabar, A.; Natakusumah, D.K.; Samaulah, H. Effects of watershed topography and land use on baseflow hydrology in upstream Komering South Sumatera, Indonesia. Int. J. GEOMATE 2019, 17, 28-33. [CrossRef]

24. Chernet, T. Hydrogeology of Ethiopia and Water Resouces Development; Ethiopian Institute of Geological Survey, Ministry of Mines and Energy: Addis Ababa, Ethiopia, 1993; p. 227.

25. Demlie, M.; Wohnlich, S.; Ayenew, T. Major ion hydrochemistry and environmental isotope signatures as a tool in assessing groundwater occurrence and its dynamics in a fractured volcanic aquifer system located within a heavily urbanized catchment, central Ethiopia. J. Hydrol. 2008, 353, 175-188. [CrossRef]

26. Alemayehu, T. Determination of Groundwater-Surface Water Interaction and Trans-Boundary Flow. Ph.D. Thesis, Ethiopian Institute of Water Resources, Addis Ababa, Ethiopia, 2016; p. 231.

27. SELKHOZPROMEXPORT. Baro-Akobo Basin Masterplan Study of Water and Land Resources of the Gambela Plain; SELKHOZPROMEXPORT: Moscow, Russia, 1990; Volume IV, p. 82.

28. Abbate, E.; Bruni, P.; Sagri, M. Geology of Ethiopia: A Review and Geomorphological Perspectives. Landsc. Landf. Ethiop. 2015, 53, 33-59. [CrossRef]

29. Geological Survey of Ethiopia. GSE Geology of Ethiopia; Geological Survey of Ethiopia: Addis Ababa, Ethiopia, 2016.

30. Tesema, Z. Report on Water well Drilling Site Selection in Yayu Coal Field, Southwestern Ethiopia; Geological Survey of Ethiopia: Addis Ababa, Ethiopia, 2003; p. 11.

31. Kazmin, V.; Warden, A.J. Explanation of the Geological Map of Ethiopia; Geological Survey of Ethiopia: Addis Ababa, Ethiopia, 1975; p. 18.

32. Ilubabor Zone Water Resources Office. Water supply study document. Unpubl. Rep. 2012, 53, 1689-1699.

33. Ayenew, T.; Demlie, M.; Wohnlich, S. Hydrogeological framework and occurrence of groundwater in the Ethiopian aquifers. J. African Earth Sci. 2008, 52, 97-113. [CrossRef]

34. Asfaw, B.; Abaire, B.; Tefera, G. Hydrogeological Report of Gore Area (NC36-16); Ethiopian Institute of Geological Survey: Addis Ababa, Ethiopia, 2001; p. 32.

35. Kebede, S. Groundwater in Ethiopia: Features, Numbers and Opportunities; Springer: New York, NY, USA, 2013; ISBN 978-3-642-30391-3.

36. Mohr, P.A. Mapping of the Major Structures of the African Rift System; Smithsonian Astrophysical Observatory: Cambridge, MA, USA, 1974; p. 70.

37. Henricksen, B.L.; Ross, S.; Tilimo, S.; Wijntje-Bruggeman, H.Y. Geomorphology and Soils. UNDP; FAO: Rome, Italy, $1984 ;$ p. 804.

38. Driessen, P.; Deckers, J.; Spaargaren, O. Lecture Notes on the Major Soil of the World; FAO: Rome, Italy, 2001; Volume 2006, ISBN 9251046379.

39. World Meteorological Organization. WMO Guidelines on the Calculation of Climate Normals; World Meteorological Organization: Geneva, Switzerland, 2017; p. 18.

40. Searcy, J.K. Flow-Duration Curves, Manual of Hydrology: Part 2. Low-Flow Techniques, Methods and practices of the Geological Survey; United States Government Printing Office: Washington, DC, USA, 1969; p. 33.

41. Vogel, R.M.; Fennessey, N.M. Flow Duration Curves II. Water Resour. Bull. 1996, 31, 1029-1039. [CrossRef]

42. Welderufael, W.A.; Woyessa, Y.E. Stream flow analysis and comparison of base flow separation methods: Case study of the Modder River Basin in Central South Africa. Eur. Water 2010, 31, 3-12.

43. Mohammed, R.; Scholz, M. Flow-duration curve integration into digital filtering algorithms for simulating climate variability based on river baseflow. Hydrol. Sci. J. 2018, 63, 1558-1573. [CrossRef]

44. Furat, A.M.; Al-Faraj, M.S. Incorporation of the Flow Duration Curve Method Within Digital Filtering Algorithms to Estimate the Base Flow Contribution to Total Runoff. Water Resour. Manag. 2014, 28, 5477-5489. [CrossRef]

45. Lott, D.A.; Stewart, M.T. Base flow separation: A comparison of analytical and mass balance methods. J. Hydrol. 2016, 535, 525-533. [CrossRef]

46. Zhang, Y.; Ahiablame, L.; Enge, B.; Liu, J. Regression modeling of baseflow and baseflow index for Michigan USA. Water 2013, 5, 1797-1815. [CrossRef]

47. Dingman, S.L. Physical Hydrology, 3rd ed.; Waveland Press, Inc.: Long Grove, IL, USA, 2015; ISBN 1478628073.

48. Freez, R.A.; Cherry, J.A. Groundwater; Prentice-Hall, Inc.: Englewood Cliffs, NJ, USA, 1979; ISBN 0133653129. 
49. Raghunath, H.M. Hydrology (Principles, Analysis and Design), 2nd ed.; New Age International (P) Ltd.: New Delhi, India, 2006; ISBN 9781626239777.

50. Sloto, R.A.; Crouse, M.Y. Hysep: A Computer Program for Streamflow Hydrograph Separation and Analysis; U.S. Geological Survey: Waterfront Drive Pittsburgh, PA, USA, 1996; p. 54.

51. Rutledge, A.T. Development, Analysis, and Application of RORA and PART for Estimating Groundwater Recharge and Discharge in Humid Settings-A Resource for Frequently Asked Questions about the Programs; U.S. Geological Survey: Richmond, VA, USA, 2015; p. 16.

52. Piggott, A.R.; Syed Moin, C.S. A revised approach to the UKIH method for the calculation of baseflow. Hydrol. Sci. J. 2005, 50, 911-920. [CrossRef]

53. Arnold, J.G. Allen Automated Methods for Estimating Baseflow and Groundwater Recharge from Streamflow Records. J. Am. Water Resour. Assoc. 1999, 35, 13353-13366. [CrossRef]

54. Vincent Lyne, M.H. Stochastic Time-Variable Rainfall-Runoff Modeling; Australian National Conference publication: Perth, Australia, 1979; pp. 89-92.

55. Price, K. Effects of watershed topography, soils, land use, and climate on baseflow hydrology in humid regions: A review. Prog. Phys. Geogr. 2011, 35, 465-492. [CrossRef]

56. Eckhardt, K. How to construct recursive digital filters for baseflow separation. Hydrol. Process. 2005, 19, 507-515. [CrossRef]

57. Chapman, T. A comparison of algorithms for stream flow recession and baseflow separation. Hydrol. Process. 1999, 13, 701-714. [CrossRef]

58. Mohammed, R.; Scholz, M. Impact of climate variability and streamflow alteration on groundwater contribution to the base flow of the Lower Zab River (Iran and Iraq). Environ. Earth Sci. 2016, 75, 1-11. [CrossRef]

59. Stewart, M.K. Promising new baseflow separation and recession analysis methods applied to streamflow at Glendhu Catchment, New Zealand. Hydrol. Earth Syst. Sci. 2015, 19, 2587-2603. [CrossRef]

60. Lim, K.J.; Engel, B.A.; Tang, Z.; Choi, J.; Kim, K.-S.; Muthukrishnan, S.; Tripathy, D. Automated Web GIS based hydrograph analysis tool, WHAT. J. Am. Water Resour. Assoc. 2005, 41, 1407-1416. [CrossRef]

61. Barlow, P.M.; Cunningham, W.L.; Zhai, T.; Gray, M. U.S. Geological Survey Groundwater Toolbox, a Graphical and Mapping Interface for Analysis of Hydrologic Data (Version 1.0)-User Guide for Estimation of Base Flow, Runoff, and Groundwater Recharge from Streamflow Data; U.S. Geological Survey: Richmond, VA, USA, 2015; p. 27.

62. Gregor, M. User's Manual: BFI+ 3.0. HydrOffice Software Package, Water Science. 2010. Available online: https:/ /hydrooffice. org/Tool/BFI (accessed on 10 May 2021). 